OPEN ACCESS

Edited by:

Danielle K. Sandsmark, University of Pennsylvania,

United States

Reviewed by:

Yuan Xinxu,

Virginia Commonwealth University,

United States

Danilo Cardim,

University of Texas Southwestern

Medical Center, United States

Brandon Foreman,

University of Cincinnati, United States

*Correspondence:

F. A. Zeiler

Frederick.Zeiler@umanitoba.ca

Specialty section:

This article was submitted to Translational Pharmacology,

a section of the journal

Frontiers in Pharmacology

Received: 04 March 2021

Accepted: 22 October 2021

Published: 24 November 2021

Citation:

Batson C, Gomez A, Sainbhi AS,

Froese $L$ and Zeiler FA (2021) Association of Age and Sex With Multi-

Modal Cerebral Physiology in Adult

Moderate/Severe Traumatic Brain Injury: A Narrative Overview and Future Avenues for Personalized Approaches.

Front. Pharmacol. 12:676154.

doi: 10.3389/fphar.2021.676154

\section{Association of Age and Sex With Multi-Modal Cerebral Physiology in Adult Moderate/Severe Traumatic Brain Injury: A Narrative Overview and Future Avenues for Personalized Approaches}

\author{
C. Batson ${ }^{1}$, A. Gomez ${ }^{1,2}$, A. S. Sainbhi ${ }^{3}$, L. Froese ${ }^{3}$ and F. A. Zeiler ${ }^{1,2,3,4,5 *}$ \\ ${ }^{1}$ Department of Human Anatomy and Cell Science, Rady Faculty of Health Sciences, University of Manitoba, Winnipeg, MB, \\ Canada, ${ }^{2}$ Section of Neurosurgery, Department of Surgery, Rady Faculty of Health Sciences, University of Manitoba, Winnipeg, \\ MB, Canada, ${ }^{3}$ Biomedical Engineering, Faculty of Engineering, University of Manitoba, Winnipeg, MB, Canada, ${ }^{4}$ Centre on Aging, \\ University of Manitoba, Winnipeg, MB, Canada, ${ }^{5}$ Division of Anaesthesia, Department of Medicine, Addenbrooke's Hospital, \\ University of Cambridge, Cambridge, United Kingdom
}

The impact of age and biological sex on outcome in moderate/severe traumatic brain injury (TBI) has been documented in large cohort studies, with advanced age and male sex linked to worse long-term outcomes. However, the association between age/biological sex and high-frequency continuous multi-modal monitoring ( $\mathrm{MMM}$ ) cerebral physiology is unclear, with only sparing reference made in guidelines and major literature in moderate/severe TBI. In this narrative review, we summarize some of the largest studies associating various highfrequency MMM parameters with age and biological sex in moderate/severe TBI. To start, we present this by highlighting the representative available literature on high-frequency data from Intracranial Pressure (ICP), Cerebral Perfusion Pressure (CPP), Extracellular Brain Tissue Oxygenation $\left(\mathrm{PbtO}_{2}\right)$, Regional Cerebral Oxygen Saturations $\left(\mathrm{rSO}_{2}\right)$, Cerebral Blood Flow (CBF), Cerebral Blood Flow Velocity (CBFV), Cerebrovascular Reactivity (CVR), Cerebral Compensatory Reserve, common Cerebral Microdialysis (CMD) Analytes and their correlation to age and sex in moderate/severe TBI cohorts. Then we present current knowledge gaps in the literature, discuss biological implications of age and sex on cerebrovascular monitoring in $\mathrm{TBI}$ and some future avenues for bedside research into the cerebrovascular physiome after TBI.

Keywords: aging, cerebral physiology, sex, TBI - traumatic brain injury, traumatic brain injury (craniocerebral trauma)

\section{INTRODUCTION}

Bedside care for moderate and severe traumatic brain injury (TBI) has made significant advances in the past few decades (Hutchinson and O'Phelan, 2014; Carney et al., 2017; Hawryluk et al., 2019; Chesnut et al., 2020). There has been adoption of clinical practice guidelines, to standardize the basics of care (Carney et al., 2017; Hawryluk et al., 2019; Chesnut et al., 2020). Furthermore, we have seen the adoption of multi-modal monitoring (MMM) in neurocritical care (Hutchinson and O'Phelan, 
2014; Donnelly et al., 2019), with varying application in the TBI population. These devices, both invasive and non-invasive (Zeiler et al., 2020a), provide complementary information regarding cerebral physiology, so as to improve our understanding beyond that of just intracranial pressure (ICP) and cerebral perfusion pressure (CPP). Such MMM in TBI includes: brain tissue oxygen monitoring $\left(\mathrm{PbtO}_{2}\right)$ (Okonkwo et al., 2017; Zeiler et al., 2020a; Chesnut et al., 2020), parenchymal cerebral blood flow (CBF) monitoring (Mathieu et al., 2019a), cerebral blood flow velocity (CBFV) using transcranial Doppler (TCD) ultrasonography (Czosnyka et al., 1996a; Sorrentino et al., 2011; Budohoski et al., 2012; Hutchinson and O'Phelan, 2014; Zeiler et al., 2017a), regional cerebral oxygen saturations through fixed wavelength near infrared spectroscopy (NIRS) (Mathieu et al., 2019b), and serial extracellular chemistry assessments using cerebral microdialysis (CMD) (Timofeev et al., 2011; Hutchinson et al., 2015; Zeiler et al., 2017b; Zeiler et al., 2017c). Many of these devices are still in their infancy regarding application and available literature to support widespread adoption. However, some, such as $\mathrm{PbtO}_{2}$, are emerging as promising new continuous techniques with robust associations with clinical outcome (Okonkwo et al., 2017; Chesnut et al., 2020).

Aside from raw physiologic measures from the above listed MMM devices, there is also an emerging literature body regarding derived metrics of cerebral physiology (Czosnyka et al., 1997; Gao et al., 2017; Calviello et al., 2018; Zeiler et al., 2020a). Such methods employ biomedical engineering techniques of highfrequency signal acquisition and processing of raw recorded physiology, to derive new measures of cerebral physiology. The most widespread discussed metrics are those of continuous cerebrovascular reactivity (Czosnyka et al., 1997; Zeiler et al., 2017d; Zeiler et al., 2019a), which facilitate highfrequency real-time assessment of cerebral autoregulation. The exemplar in this instance would be the pressure reactivity index (PRx) (Czosnyka et al., 1997), which is derived from the correlation between slow-wave vasogenic fluctuation in ICP and mean arterial pressure (MAP), though many others exist in the literature (Zeiler et al., 2017a; Zeiler et al., 2017d; Zeiler et al., 2017e). Aside from cerebrovascular reactivity, other derived measures exist, including: cerebral compensatory reserve monitoring (Calviello et al., 2018; Zeiler et al., 2019b) and entropy metrics (Gao et al., 2017; Zeiler et al., 2020b). PRx has received the most attention, with strong associations with long-term outcomes in adult TBI (Czosnyka et al., 1997; Sorrentino et al., 2012; Zeiler et al., 2019c; Bennis et al., 2020; Zeiler et al., 2020b). However, all such derived measures have been shown to carry some degree of prognostic information (Le Roux et al., 2014).

In addition to this array of modalities and derived cerebral physiologic metrics, the data update frequency at the bedside has drastically increased in the past 10 years (Le Roux et al., 2014; Zeiler et al., 2020a). Classically, studies in moderate/severe TBI and therapeutic guidelines (Carney et al., 2017; Hawryluk et al., 2019; Chesnut et al., 2020) have relied on low-frequency cerebral physiologic data (such as ICP and CPP) recorded in bedside nursing charts. Frequency of such recordings often consisted of point measures recorded hourly, neglecting higher frequency changes or secondary injury patterns. High-frequency (i.e., $100 \mathrm{~Hz}$ or higher) data streams are being increasingly relied upon for continuous assessments of cerebral physiologic insult burden, using the percent time spent above known critical thresholds to characterize the burden of secondary injury (Güiza et al., 2015; Zeiler et al., 2019a; Zeiler et al., 2020c; Donnelly et al., 2020; Akerlund et al., 2020). These insult burden measures have been shown in moderate/severe TBI to provide improved prognostic capacity over classical low-frequency point measures or grand mean values of large epochs of time (Güiza et al., 2017; Donnelly et al., 2020; Åkerlund et al., 2020). Further, as derived cerebral physiologic metrics, such as cerebrovascular reactivity measures, are displaying treatment independence (Zeiler et al., 2019d; Froese et al., 2021) and strong associations with long-term global outcome in moderate/severe TBI, it becomes increasingly clear that such data streams are critical for future work in TBI care.

However, despite the promising nature of MMM, and their high-frequency physiologic data streams, in moderate/severe TBI care and monitoring, there exists many gaps in knowledge, which limit their widespread adoption and interpretation. Of particular importance is the impact of aging and sex on MMM metrics. Age in TBI is a well-known independent prognostic factor (Lingsma et al., 2013; Carney et al., 2017; Maas et al., 2017), with advanced age linked to worse outcomes. Similarly, various studies have documented disparity in long-term outcomes based on sex, despite most moderate/severe TBI populations being dominated by males (Zeiler et al., 2019e; Mikolic et al., 2020). Such biologic sex related differences in moderate/severe TBI outcomes have led to exploration into the impact of sex hormones on secondary injury pathways. Progesterone has been explored extensively in both pre-clinical models, demonstrating reduced neural tissue loss in models receiving exogenous supplementation (Clevenger et al., 2018; Khaksari et al., 2018). These potential benefits of progesterone have led to numerous randomized controlled trials in humans on progesterone supplementation in moderate/severe TBI, with recent meta-analyses demonstrating potentially reduced early mortality (risk ratio $(\mathrm{RR})=0.95 ; 95 \% \mathrm{CI}=0.42-0.81 ; p=$ $0.001)$ and improved early neurological outcomes $(R R=1.51$; $95 \%$ CI $=1.12-2.02 ; p=0.007$ ) (Pan et al., 2019), without sustained long-term differences between cohorts ( $\mathrm{Lu}$ et al., 2016). However, the exact influence of age and sex on specific MMM based cerebral physiologic measures is often buried, or glossed over, in large TBI outcome studies, where only passing reference may be made between age/sex and monitoring data (Czosnyka et al., 2005; Burkhart et al., 2011; Donnelly et al., 2019; Zeiler et al., 2020b). Historically, much of this limited exploration stemmed from low-resolution point-measured physiology data, which failed to lend itself to more complex analysis on insult burden of cerebral physiologic dysfunction. Yet, recently there has been a shift to recording and archiving of higher frequency digital physiologic data (Czosnyka et al., 1994; Howells et al., 2012; Hutchinson and O'Phelan, 2014; Hawryluk et al., 2020), with various studies emerging in the MMM field in TBI. As such, the biological impact of age and sex on such monitoring metrics in TBI deserves re-evaluation. 
Knowledge here could improve our ability to prognosticate in TBI, while also potentially provide us with an ability to forecast acute phase physiology based on age and sex profiles. Further, with the undertaking of randomized controlled trials in MMM in TBI, particularly for $\mathrm{PbtO}_{2}$ directed therapies (Okonkwo et al., 2017) and cerebrovascular reactivity based individualized CPP targets (Beqiri et al., 2019), understanding the impact of age and sex on this physiology may help us understand potential subgroups of responders/non-responders.

The purpose of this narrative review is to outline some of the major selected studies pertaining to the impact of age and sex on continuous high-frequency MMM based cerebral physiology in moderate/severe TBI. Further, we explore some of the potential biological explanations for discrepancies seen in such physiologic measures, as they relate to cerebrovascular function/dysfunction. Finally, we will provide some suggestions for future directions into researching the link between aging and sex, with high-fidelity MMM of cerebral physiology in moderate/severe TBI. Of note, for many devices the literature is limited in this area, and only a small number of studies have been commented on. This review is by no means an exhaustive categorization of every study exploring an association between MMM devices and age/sex, but instead aims to provide an overview of the prominent literature, or lack thereof, on this topic.

\section{STANDARD MONITORING IN TRAUMATIC BRAIN INJURY}

\section{Intracranial Pressure and Cerebral Perfusion Pressure}

ICP monitoring, through invasive means, forms the crux of current guideline based management of moderate/severe TBI, with a current threshold for treatment of $22 \mathrm{mmHg}$ (Sorrentino et al., 2012; Carney et al., 2017). Similarly, CPP the second element of current TBI care, which is actively targeted to a range of 60-70 $\mathrm{mmHg}$, and is derived based on the simple formula: CPP = MAP - ICP (Carney et al., 2017). Time spent above the defined ICP thresholds, and outside of the suggested target CPP range, have both been documented to be associated with worse long-term outcome in moderate/severe TBI (Güiza et al., 2017; Donnelly et al., 2020). The major studies in these areas with high-frequency data show that older patients tended to have high ICPs and low CPPs and suffer undesirable outcomes (Czosnyka et al., 2005; Czosnyka et al., 2008). Males were predominant in these studies therefore leading in numbers for fatal outcomes.

Exploring age and ICP/CPP in more detail, it is clear that MMM based high-frequency ICP and CPP have not been directly evaluated in association with age and biological sex. Adams et al. compared the mean ICP and CPP of patients in functional survivors and fatal outcome groups (Adams et al., 2017). Patients in the functional survivors group were younger with mean age $38 \pm 16$ years vs. $45 \pm 18$ years $(p<0.001)$ for patients in fatal outcomes group (Adams et al., 2017). Patients in the functional survivors group compared to the fatal outcome group, had lower mean ICP and higher mean CPP $(15.1 \pm 8.2 \mathrm{mmHg}$ vs. $21.0 \pm 10.2 \mathrm{mmHg}(p<0.001)$; and
$78.5 \pm 8.0 \mathrm{mmHg}$ vs. $75.9 \pm 8.3 \mathrm{mmHg}(p=0.009)$, respectively) (Adams et al., 2017). Nourallah et al. compared the mean ICP and CPP of patients in favourable outcome and unfavourable outcome groups as defined by GOS (Nourallah et al., 2018). Patients in the favourable outcome group were younger with mean age of $38.2 \pm 17.0$ years vs. $43.0 \pm 17.0$ years $(p=0.0091)$ for patients in unfavourable outcome group. Patients in the favourable outcome group compared to unfavourable outcome group, had lower mean ICP $(12.6 \pm 4.6 \mathrm{mmHg}$ vs. $15.4 \pm 19.5 \mathrm{mmHg}, p=$ $0.0039)$ but no difference in CPP was found $(77.6 \pm 6.7 \mathrm{mmHg}$ vs. 77.6 $\pm 9.9, p=0.31$ ) (Nourallah et al., 2018). Czosnyka et al. showed in a 2005 study that mean ICP slightly decreased with age from $19 \pm 12 \mathrm{mmHg}$ to $15 \pm 6 \mathrm{mmHg}(p<0.004)$ and mean CPP increased with age from $72 \pm 14 \mathrm{mmHg}$ to $79 \pm 12 \mathrm{mmHg}(p<0.001)$ (Czosnyka et al., 2005). Though interpretation of these results must be cautioned, given the primary goal of the analysis in the parent manuscripts was outcome association. Many factors confound patient care trajectories and outcomes, such as institutional treatment guidelines/practices and goals of care discussions between health care providers and families. As such, one cannot directly presume that given younger patients had a higher rate of survival, and the survival groups had lower ICP (or higher CPP), that younger patients have lower ICP/higher CPP. Such inferences should be discouraged at this time.

With regards to biological sex, in the study by Sorrentino et al., it is seen that ICP threshold for survival was lower in males compared to females at 22 vs. $23 \mathrm{mmHg}(p<0.001)$, and lower in patients $>55$ years of age compared to young, at $21 \mathrm{vs.} 23 \mathrm{mmHg}$ respectively ( $p=0.018$ ) (Sorrentino et al., 2012). Furthermore, the CPP threshold for survival in that study was higher in older patients ( $>55$ years) at 75 vs. $70 \mathrm{mmHg}$ in young patients $(p=$ 0.047), regardless of sex. The first study by Czosnyka et al. showed that females $<50$ years had more fatal outcomes than males, with a $29 \%$ death rate in females compared to a $17 \%$ death rate in males ( $p=0.026)$ (Czosnyka et al., 2008).

It must be emphasized that most large studies on highresolution (i.e., full waveform) ICP/CPP failed to comment on any detailed statistical association between age or biological sex, other than gross groupings of male vs. female, and arbitrary binary age cutoffs. Further to this, the multi-variable covariance patterns for ICP and CPP were not commented on, only simple comparative statistics have been employed. The studies outlined, are the largest representative studies found, but are by no means exhaustive of all studies documenting the link between ICP/CPP and age/sex. Table 1 provides a summary of selected large studies showing the relationship of these parameters with age and sex.

\section{Extracellular Brain Tissue Oxygenation - $\mathrm{PbtO}_{2}$}

$\mathrm{PbtO}_{2}$ is measured using an intraparenchymal Clarke electrode, which assesses extracellular diffusible oxygen levels of the brain parenchyma. Threshold by which intervention is currently suggested by guideline-based approaches is $20 \mathrm{mmHg}$, values below this are linked to poor outcomes (Okonkwo et al., 2017; Chesnut et al., 2020). This association has triggered ongoing phase III trials in TBI. There are few studies in the literature 
TABLE 1 | Main representative studies evaluating link between ICP/CPP and PbtO2 with age/biological sex.

\begin{tabular}{|c|c|c|c|c|c|}
\hline References & Monitoring technique & $\begin{array}{l}\text { Number of } \\
\text { patients }\end{array}$ & Patient characteristics & Relevant results & Relevant conclusions \\
\hline \multicolumn{6}{|c|}{$\mathrm{ICP}$} \\
\hline $\begin{array}{l}\text { Czosnyka } \\
\text { et al. (2008) }\end{array}$ & $\begin{array}{l}\text { - Intraparenchymal probe } \\
\text { (Camino ICP transducer in } 12 \\
\text { patients and Codman ICP } \\
\text { Microsensors in } 566 \text { patients) } \\
\text { or via a ventricular drain and an } \\
\text { external pressure transducer } \\
\text { (34 patients) }\end{array}$ & $\begin{array}{l}612 \text { total } \\
\text { patients, } 469 \\
\text { with ICP data }\end{array}$ & $\begin{array}{l}\text { - Severe TBI } \\
\text { - Median admission GCS was } 6 \\
\text { in both males and females }\end{array}$ & $\begin{array}{l}\text { - Sex: } 371 \text { males; } 98 \text { females } \\
\text { - Mean age: females } 34 \text { SD } \\
\text { 16.5 years } \\
\text { Males } 34 \text { SD } 17 \text { years }\end{array}$ & $\begin{array}{l}\text { - There was no notable difference } \\
\text { amongst males and females } \\
\text { above or below } 50 \text { years of age in } \\
\text { mean ICP } \\
\text { - Females <50 years old had a } \\
\text { notably greater rate of fatal } \\
\text { outcome at } 6 \text { months compared } \\
\text { to males } \\
\text { - } 29 \% \text { mortality was evident in } \\
\text { females }(\mathrm{N}=344 ; p=0.026) \text { vs. } \\
17 \% \text { in males }\end{array}$ \\
\hline $\begin{array}{l}\text { Adams et al. } \\
(2017)\end{array}$ & $\begin{array}{l}\text { - Intraparenchymal microsensor } \\
\text { (Codman) }\end{array}$ & $\begin{array}{l}601 \text { total } \\
\text { patients, } 556 \\
\text { with ICP data }\end{array}$ & $\begin{array}{l}\text { - Severe TBI } \\
\text { - Based on total cohort of } \\
\text { patients (601): best pre- } \\
\text { intubation GCS 3-8 in } 435 \\
\text { patients and 9-15 in } 166 \\
\text { patients } \\
\text { - Two groups of patients were } \\
\text { monitored } \\
\text { Based on } 556 \text { patients with ICP } \\
\text { data: best pre-intubation GCS } \\
\text { in Functional Survivors group } \\
\text { was 3-8 in } 329 \text { patients and } \\
\text { 9-15 in } 139 \text { patients } \\
\text { In Fatal Outcome group was } \\
\text { 3-8 in } 71 \text { patients and 9-15 in } \\
17 \text { patients }\end{array}$ & $\begin{array}{l}\text { - Sex: based on total cohort } \\
\text { of patients (601): } 464 \\
\text { males, } 137 \text { females } \\
\text { Based on } 556 \text { patients with } \\
\text { ICP data: Functional } \\
\text { Survivors group: } 360 \text { males, } \\
108 \text { females } \\
\text { Fatal Outcome group: } 68 \\
\text { males, } 20 \text { females } \\
\text { - Mean age: based on total } \\
\text { cohort of patients ( } 601): 39 \\
\text { SD } 17 \text { years } \\
\text { Based on } 556 \text { patients with } \\
\text { ICP data: Functional } \\
\text { Survivors group: } \\
38 \pm 16 \text { years } \\
\text { Fatal Outcome group: } \\
45 \pm 18 \text { years }\end{array}$ & $\begin{array}{l}\text { - Mean ICP and SD in Functional } \\
\text { Survivors group was } \\
15.1 \pm 8.2 \mathrm{mmHg} \text { and in the Fatal } \\
\text { Outcome group was } \\
21.0 \pm 10.2 \mathrm{mmHg}, p<0.001 \\
\text { - Males were predominant in both } \\
\text { groups. The Fatal Outcome } \\
\text { group had older patients with } \\
\text { higher mean ICPs }\end{array}$ \\
\hline $\begin{array}{l}\text { Sorrentino } \\
\text { et al. (2012) }\end{array}$ & $\begin{array}{l}\text { - Intraparenchymal transducer } \\
\text { (Codman) }\end{array}$ & 459 & $\begin{array}{l}\text { - Mild to severe TBI } \\
\text { - Median admission GCS was } 7 \\
\text { range } 3-15 \text {, IQR } 5 \\
338 \text { patients had GCS } \leq 8 \text { and } \\
121 \text { patients had a GCS } \geq 9\end{array}$ & $\begin{array}{l}\text { - Sex: } 359 \text { males; } 100 \\
\text { females } \\
\text { - Median age: } 34, \text { IQR } 27 \\
\text { years } \\
\text { Patients were categorized } \\
\text { into two groups } \\
\text { - Threshold for Survival was } \\
23 \text { mmHg, } p<0.001 \text { and } \\
\text { for Favourable Outcome } \\
\text { was } 22 \text { mmHg, } p<0.001 \text { in } \\
\text { patients } \leq 55 \text { years } \\
\text { - Threshold for Survival was } \\
21 \text { mmHg, } p=0.018 \text { and } \\
\text { for Favourable Outcome } \\
\text { was } 18 \text { mmHg, } p=0.023 \text { in } \\
\text { patients }>55 \text { years } \\
\text { - Threshold for Survival in } \\
\text { females was } 23 \text { mmHg, } p< \\
0.001 \text { and for Favourable } \\
\text { Outcome was } 18 \text { mmHg, } \\
p=0.004 \\
\text { - Threshold for Survival in } \\
\text { males and for Favorable } \\
\text { Outcome was } 22 \text { mmHg, } \\
p<0.001\end{array}$ & $\begin{array}{l}\text { - ICP Threshold for Survival and } \\
\text { Favourable Outcome was lower } \\
\text { in patients }>55 \text { years and higher } \\
\text { in patients } \leq 55 \text { years } \\
\text { - ICP Threshold for Survival was } \\
\text { lower in males and higher in } \\
\text { females and for Favourable } \\
\text { Outcome was lower in females } \\
\text { and higher in males } \\
\text { - ICP threshold was lower in } \\
\text { females and patients }>55 \text { years } \\
\text { old for Favourable Outcomes } \\
\text { suggesting they were more } \\
\text { vulnerable to intracranial } \\
\text { hypertension }\end{array}$ \\
\hline
\end{tabular}


TABLE 1 | (Continued) Main representative studies evaluating link between ICP/CPP and PbtO2 with age/biological sex.

\begin{tabular}{|c|c|c|c|c|c|}
\hline References & Monitoring technique & $\begin{array}{c}\text { Number of } \\
\text { patients }\end{array}$ & Patient characteristics & Relevant results & Relevant conclusions \\
\hline $\begin{array}{l}\text { Czosnyka } \\
\text { et al. (2005) }\end{array}$ & $\begin{array}{l}\text { - Intraparenchymal probe } \\
\text { (Camino ICP transducer in } 12 \\
\text { patients and Codman ICP } \\
\text { Microsensors in } 346 \text { patients) }\end{array}$ & 358 & $\begin{array}{l}\text { - Mild to severe TBI } \\
\text { - Initial GCS scores ranged from } \\
\text { 3-15, } 20 \% \text { patients had a } \\
\text { GCS score above } 8\end{array}$ & $\begin{array}{l}\text { - Sex: } 288 \text { males; } 60 \text { females } \\
\text { - Age range: } 16-87 \text { years }\end{array}$ & $\begin{array}{l}\text { - Study showed that elderly people } \\
\text { suffered worse outcomes } \\
\text { post TBI } \\
\text { - Mean ICP decreased with age } \\
(r=-0.14, p<0.01)\end{array}$ \\
\hline $\begin{array}{l}\text { Nourallah } \\
\text { et al. (2018) }\end{array}$ & $\begin{array}{l}\text { - ICP: Intraparenchymal Strain } \\
\text { gauze probe (Codman) }\end{array}$ & 355 & $\begin{array}{l}\text { - Moderate to severe TBI } \\
\text { - GCS median was } 7 \text { IQR 3-9 }\end{array}$ & $\begin{array}{l}\text { - Sex: } 271 \text { males; } 84 \text { females } \\
\text { Two groups of patients were } \\
\text { monitored } \\
\text { In Favourable Outcome } \\
\text { group: } 133 \text { males, } 39 \\
\text { females and in Unfavourable } \\
\text { Outcome group: } 138 \text { males, } \\
45 \text { females } \\
\text { - Mean age: } 40.6 \text { SD } 17.2 \\
\text { years } \\
\text { In Favourable Outcome } \\
\text { group: } 38.2 \text { SD } 17.0 \text { years } \\
\text { and in Unfavourable } \\
\text { Outcome group: } 43.0 \text { SD } \\
\text { 17.0 years }\end{array}$ & $\begin{array}{l}\text { - Mean ICP overall was 14.1 SD } \\
7.7 \mathrm{mmHg} \text {, in the Favourable } \\
\text { Outcome (GOS } \geq 4) \text { group was } \\
\text { 12.6 SD } 4.6 \mathrm{mmHg} \text { and in the } \\
\text { Unfavourable Outcome group } \\
\text { (GOS <4) was } 15.4 \mathrm{SD} \\
19.5 \mathrm{mmHg}, p=0.0039 \text { for both } \\
\text { groups } \\
\text { - Mean ICP and age were higher in } \\
\text { the Unfavourable Outcome group } \\
\text { and lower in the Favourable } \\
\text { Outcome group }\end{array}$ \\
\hline
\end{tabular}

\begin{tabular}{|c|c|c|c|c|c|}
\hline \multicolumn{6}{|c|}{ CPP } \\
\hline $\begin{array}{l}\text { Czosnyka } \\
\text { et al. (2008) }\end{array}$ & $\begin{array}{l}\text { - ICP: intraparenchymal probe } \\
\text { (Camino ICP transducer in } 12 \\
\text { patients and Codman ICP } \\
\text { Microsensors in } 566 \text { patients) }\end{array}$ & $\begin{array}{l}612 \text { total } \\
\text { patients, } 469 \\
\text { with CPP } \\
\text { data }\end{array}$ & $\begin{array}{l}\text { - Severe TBI } \\
\text { - Median admission GCS was } 6 \\
\text { in both males and females }\end{array}$ & $\begin{array}{l}\text { - Sex: } 371 \text { males; } 98 \text { females } \\
\text { - Mean age: females } 34 \text { SD } \\
\text { 16.5 years } \\
\text { Males } 34 \text { SD } 17 \text { years }\end{array}$ & $\begin{array}{l}\text { - There was no notable difference } \\
\text { amongst males and females } \\
\text { above or below } 50 \text { years of age in } \\
\text { mean CPP }\end{array}$ \\
\hline
\end{tabular}

or via a ventricular drain and an external pressure transducer (34 patients)

- ABP: indwelling arterial catheter in the radial artery

\begin{tabular}{|c|c|c|c|}
\hline $\begin{array}{l}\text { Adams } \\
\text { et al. (2017) }\end{array}$ & $\begin{array}{l}\text { - ICP: intraparenchymal } \\
\text { microsensor (Codman) } \\
\text { - ABP: radial or femoral artery }\end{array}$ & $\begin{array}{l}601 \text { total } \\
\text { patients, } 556 \\
\text { with CPP } \\
\text { data }\end{array}$ & $\begin{array}{l}\text { - Severe TBI } \\
\text { - Based on total cohort of } \\
\text { patients (601): best pre- } \\
\text { intubation GCS 3-8 in } 435 \\
\text { patients and 9-15 in } 166 \\
\text { patients } \\
\text { - Two groups of patients were } \\
\text { monitored } \\
\text { Based on } 556 \text { patients with ICP } \\
\text { data: best pre-intubation GCS } \\
\text { in Functional Survivors group } \\
\text { was 3-8 in } 329 \text { patients and } \\
\text { 9-15 in } 139 \text { patients } \\
\text { In Fatal Outcome group was } \\
3-8 \text { in } 71 \text { patients and 9-15 in } \\
17 \text { patients }\end{array}$ \\
\hline
\end{tabular}
- Sex: based on total cohort of patients (601): 464 males, 137 females Based on 556 patients with CPP data: Functional Survivors group: 360 males, 108 females Fatal Outcome group: 68 males, 20 females
- Mean age: based on total
- Mean CPP plus SD in Functional Survivors group was $78.5 \pm 8.0 \mathrm{mmHg}$ and in the Fatal Outcome group was $75.9 \pm 8.3 \mathrm{mmHg}, p=0.009$
- Males were predominant in both groups
- The fatal outcome group had older patients with lower mean CPPs cohort of patients (601): 39 SD 17 years Based on 556 patients with CPP data: Functional

Survivors group: $38 \pm 16$ years Fatal Outcome group: $45 \pm 18$ years
- Females <50 years old had a notably greater rate of fatal outcome at 6 months compared to males

$29 \%$ mortality was evident in females ( $\mathrm{N}=344 ; p=0.026$ ) vs. $17 \%$ in males

(Continued on following page) 
TABLE 1 | (Continued) Main representative studies evaluating link between ICP/CPP and PbtO2 with age/biological sex.

\begin{tabular}{|c|c|c|c|c|c|}
\hline References & Monitoring technique & $\begin{array}{c}\text { Number of } \\
\text { patients }\end{array}$ & Patient characteristics & Relevant results & Relevant conclusions \\
\hline $\begin{array}{l}\text { Sorrentino } \\
\text { et al. (2012) }\end{array}$ & $\begin{array}{l}\text { - ICP: Intraparenchymal } \\
\text { transducer (Codman) } \\
\text { - ABP: invasively measured from } \\
\text { the radial or dorsalis pedis } \\
\text { artery }\end{array}$ & 459 & $\begin{array}{l}\text { - Mild to severe TBI } \\
\text { - Median admission GCS was } 7 \\
\text { range } 3-15, \text { IQR } 5 \\
338 \text { patients had GCS } \leq 8 \text { and } \\
121 \text { patients had a GCS } \geq 9\end{array}$ & $\begin{array}{l}\text { - Sex: } 359 \text { males; } 100 \\
\text { females } \\
\text { - Median age: } 34, \text { IQR } \\
27 \text { years } \\
\text { Patients were categorized } \\
\text { into two groups } \\
\text { - Threshold for Survival and } \\
\text { Favourable Outcome was } \\
70 \text { mmHg } \\
\text { - Threshold for Survival was } \\
75 \text { mmHg in those } \\
>55 \text { years old, } p=0.047 \\
\text { and no threshold was found } \\
\text { for Favourable Outcome in } \\
\text { this age group } \\
\text { - Threshold for Survival was } \\
70 \text { mmHg, } p<0.001 \text { and } \\
\text { for Favourable Outcome } \\
\text { was } 70 \text { mmHg, } p=0.001 \text { in } \\
\text { patients } \leq 55 \text { years } \\
\text { - Threshold for Survival in } \\
\text { females was } 70 \text { mmHg, } p= \\
0.021 \text { and none was found } \\
\text { for Favourable Outcome } \\
\text { - Threshold for Survival in } \\
\text { males was } 70 \text { mmHg, } p< \\
0.001 \text { and for Favorable } \\
\text { Outcome was } 70 \text { mmHg, } \\
p=0.021\end{array}$ & $\begin{array}{l}\text { - CPP threshold for survival was } \\
\text { higher in older patients and lower } \\
\text { in younger patients } \\
\text { - CPP thresholds for survival was } \\
70 \mathrm{mmHg} \text { for both males and } \\
\text { females }\end{array}$ \\
\hline $\begin{array}{l}\text { Czosnyka } \\
\text { et al. (2005) }\end{array}$ & $\begin{array}{l}\text { - ICP: intraparenchymal probe } \\
\text { (Camino ICP transducer in } 12 \\
\text { patients and Codman ICP } \\
\text { Microsensors in } 346 \text { patients) } \\
\text { - ABP: obtained invasively }\end{array}$ & 358 & $\begin{array}{l}\text { - Mild to severe TBI } \\
\text { - Initial GCS scores ranged from } \\
\text { 3-15, } 20 \% \text { patients had a } \\
\text { GCS score above } 8\end{array}$ & $\begin{array}{l}\text { - Sex: } 288 \text { males; } 60 \text { females } \\
\text { - Age range: } 16-87 \text { years } \\
\text { - A notable negative } \\
\text { relationship was seen } \\
\text { between GOS score and } \\
\text { age; } r=-0.301, p<0.0001\end{array}$ & $\begin{array}{l}\text { - Study showed that elderly people } \\
\text { suffered worse outcomes } \\
\text { post TBI } \\
\text { - Mean CPP increased with age } \\
\quad(r=0.19, p=0.0004)\end{array}$ \\
\hline $\begin{array}{l}\text { Nourallah } \\
\text { et al. (2018) }\end{array}$ & $\begin{array}{l}\text { - ICP: Intraparenchymal Strain } \\
\text { gauze probe (Codman) } \\
\text { - ABP: radial or femoral lines } \\
\text { connected to pressure } \\
\text { transducers }\end{array}$ & 355 & $\begin{array}{l}\text { - Moderate to severe TBI } \\
\text { - Median GCS was } 7 \text { IQR 3-9 }\end{array}$ & $\begin{array}{l}\text { - Sex: } 271 \text { males; } 84 \text { females } \\
\text { Two groups of patients were } \\
\text { studied: In Favourable } \\
\text { Outcome group: } 133 \text { males, } \\
39 \text { females and in } \\
\text { Unfavourable Outcome } \\
\text { group: } 138 \text { males, } 45 \\
\text { females } \\
\text { - Mean age: } 40.6 \mathrm{SD} \\
\text { 17.2 years } \\
\text { In Favourable Outcome } \\
\text { group: } 38.2 \text { SD } 17.0 \text { years } \\
\text { and in Unfavourable } \\
\text { Outcome group: } 43.0 \text { SD } \\
\text { 17.0 years }\end{array}$ & $\begin{array}{l}\text { - Mean CPP overall was } 77.5 \mathrm{SD} \\
8.5 \mathrm{mmHg} \text {, in the Favourable } \\
\text { Outcome (GOS } \geq 4 \text { ) group was } \\
\text { 77.6 SD } 6.7 \mathrm{mmHg} \text { and in the } \\
\text { Unfavourable Outcome group } \\
\text { (GOS <4) was } 77.6 \mathrm{SD} \\
9.9 \mathrm{mmHg}, p=0.31 \text { for both } \\
\text { groups } \\
\text { - Mean CPP did not show much } \\
\text { variation between groups and } \\
\text { amongst patients }\end{array}$ \\
\hline
\end{tabular}


TABLE 1 | (Continued) Main representative studies evaluating link between ICP/CPP and PbtO2 with age/biological sex.

\begin{tabular}{|c|c|c|c|c|c|}
\hline References & Monitoring technique & $\begin{array}{c}\text { Number of } \\
\text { patients }\end{array}$ & Patient characteristics & Relevant results & Relevant conclusions \\
\hline \multicolumn{6}{|c|}{$\mathrm{PbtO}_{2}$} \\
\hline $\begin{array}{l}\text { Martini et al. } \\
\text { (2009) }\end{array}$ & $\begin{array}{l}\text { - ICP: Camino monitor } \\
-\mathrm{PbO}_{2} \text { monitor }\end{array}$ & 629 & $\begin{array}{l}\text { - Severe TBI } \\
\text { - Admission GCS } \leq 8 \\
\text { Data given for males in two } \\
\text { monitored groups: } \\
\text { Mean GCS in the ICP-Only } \\
\text { group was } 5.6 \pm 2.3 \text { and in the } \\
\mathrm{PbO}_{2} \text { Monitored group was } \\
5.1 \pm 2.2\end{array}$ & $\begin{array}{l}\text { - Sex: } 465 \text { males; } 164 \\
\text { females } \\
373 \text { males monitored in } \mathrm{ICP}_{-} \\
\text {Only group and } 92 \text { in } \mathrm{PbO}_{2} \\
\text { group } \\
\text { - Mean age: of patients in } \\
\mathrm{PbO}_{2} \text { group was } 35.7 \pm 16.9 \\
\text { years and of patients in ICP- } \\
\text { Only group was } 40.7 \pm 19.6 \\
\text { years }\end{array}$ & $\begin{array}{l}\text { - Mean daily } \mathrm{PbO}_{2} \text { in } \mathrm{PbO}_{2} \text { group } \\
\text { was } 24.7 \pm 10.2 \mathrm{mmHg} \text { and none } \\
\text { was recorded for the ICP-Only } \\
\text { group } \\
\text { - It was noted that patients in } \mathrm{PbO}_{2} \\
\text { group was younger than those in } \\
\text { the ICP-only group } \\
\text { - No significant findings were made } \\
\text { regarding sex }\end{array}$ \\
\hline $\begin{array}{l}\text { Zeiler et al. } \\
\text { (2020d) }\end{array}$ & $\begin{array}{l}\text { - ICP: intraparenchymal strain } \\
\text { gauge probe (Codman) and } \\
\text { parenchymal fiber optic } \\
\text { pressure sensor (Camino) } \\
\text { - } \mathrm{PbtO}_{2} \text { Licox probe }\end{array}$ & $\begin{array}{l}185 \text { total, } 47 \\
\text { with } \mathrm{PbtO}_{2} \\
\text { data }\end{array}$ & $\begin{array}{l}\text { - Severe TBI } \\
\text { - Two groups of males were } \\
\text { studied based on Mean ICP } \\
\text { Below } 15 \mathrm{mmHg} \text { and Mean } \\
\text { ICP Above } 20 \mathrm{mmHg} \text { : Median } \\
\text { admission GCS of } 6 \text { IQR 3-7 } \\
\text { for the group with Mean ICP } \\
\text { Below } 15 \mathrm{mmHg} \text { and } 7 \text { IQR } \\
\text { 3-8 for the group with Mean } \\
\text { ICP Above } 20 \mathrm{mmHg}\end{array}$ & $\begin{array}{l}\text { - Sex: } 141 \text { males; } 44 \text { females } \\
122 \text { males monitored in the } \\
\text { group with Mean ICP Below } \\
15 \mathrm{mmHg}, 41 \text { with } \mathrm{PbtO}_{2} \\
\text { results and } 19 \text { in the group } \\
\text { with Mean ICP Above } \\
20 \mathrm{mmHg}, 6 \text { with } \mathrm{PbtO}_{2} \\
\text { results } \\
\text { - Median age: of patients in } \\
\text { Mean ICP Below } 15 \mathrm{mmHg} \\
\text { group was } 51 \text { IQR } 31-62.3 \\
\text { years and of patients in } \\
\text { Mean ICP Above } 20 \mathrm{mmHg} \\
\text { group was } 54 \text { IQR } \\
\text { 35.3-68.3 years }\end{array}$ & $\begin{array}{l}\text { - In the group with Mean ICP Below } \\
15 \mathrm{mmHg}^{\mathrm{PbtO}} \mathrm{P}_{2} \text { was } 27 \mathrm{mmHg} \\
\text { IQR 23.2-33.1 mmHg, } p=0.183 \\
\text { and in the group with Mean ICP } \\
\text { Above } 20 \mathrm{mmHg} \text {, lowering of } \\
\mathrm{PbtO}_{2} \text { to } 22.1 \mathrm{mmHg} \mathrm{IQR} \\
\text { 18.2-26.2 } \mathrm{mmHg}, p=0.183 \text { was } \\
\text { seen } \\
\text { - Older patients were part of the } \\
\text { group with high ICP and low } \\
\text { PbtO }_{2}\end{array}$ \\
\hline $\begin{array}{l}\text { Stiefel et al. } \\
(2005)\end{array}$ & $\begin{array}{l}\text { - ICP: Camino monitor } \\
-\mathrm{PbtO}_{2} \text { monitor }\end{array}$ & 53 & $\begin{array}{l}\text { - Severe TBI } \\
\text { - GCS score <8 }\end{array}$ & $\begin{array}{l}\text { - Sex: } 42 \text { males; } 11 \text { females } \\
\text { Two groups were monitored: } \\
\text { ICP/CPP-based therapy } \\
\text { group and Combined ICP/ } \\
\text { CPP and Brain Tissue } \mathrm{PO}_{2}- \\
\text { based therapy group - } 25 \\
\text { patients ( } 17 \text { males and } 8 \\
\text { females) were in the first } \\
\text { group and } 28 \text { patients ( } 25 \\
\text { males and } 3 \text { females) were in } \\
\text { the second group } \\
\text { - Mean age: of patients in the } \\
\text { ICP/CPP group was } 44 \pm 14 \\
\text { years and of patients in the } \\
\text { Brain Tissue PO } \mathrm{PO}_{2} \text { group } \\
\text { was } 38 \pm 18 \text { years }\end{array}$ & $\begin{array}{l}\text { - A mean daily brain tissue } \mathrm{PO}_{2} \text { of } \\
34.7 \pm 12.3 \mathrm{mmHg} \text { was recorded } \\
\text { - Patients who underwent ICP/ } \\
\text { CPP/Brain Tissue } \mathrm{PO}_{2} \text { directed } \\
\text { management were younger than } \\
\text { those who underwent ICP/CPP- } \\
\text { based therapy }\end{array}$ \\
\hline
\end{tabular}

$\%$ = percentage, $A B P$, arterial blood pressure; CPP, cerebral perfusion pressure; GCS, glasgow coma scale; GOS, glasgow outcome scale; ICP, intracranial pressure; IQR, interquartile range, $\mathrm{mmHg}=$ millimeters of Mercury, PbtO2 = extracellular brain tissue oxygenation, $\mathrm{PBO} 2=$ brain tissue oxygen, $P O 2=$ brain tissue oxygen tension, $\mathrm{p}=\mathrm{p}$-value, $r=$ correlation coefficient, SD, standard deviation; TBI, traumatic brain injury.

examining the association between age/sex and $\mathrm{PbtO}_{2}$ in moderate/severe TBI. Studies examined showed that older patients trended towards having lower $\mathrm{PbtO}_{2}$ and tended to suffer undesirable outcomes (Stiefel et al., 2005; Martini et al., 2009; Zeiler et al., 2020d). Though, it must be acknowledged, that all of the identified relationships failed to reach statistical significance, and only showed a potential relationship based on raw differences in mean/median magnitudes. This lack of significance occurred in the absence of adjusting for multiple comparisons, highlighting that no definitive comments on the association between $\mathrm{PbtO}_{2}$ and age/sex can truly be made at this time. Based on the Zeiler et al. study, it can be seen that older patients were part of the group with high ICP and low $\mathrm{PbtO}_{2}$
(Zeiler et al., 2020d). In this study, median age for patients in the group with mean ICP below $15 \mathrm{mmHg}$ was 51 (IQR: 31-62.3 years) vs. 54 (IQR: $35.3-68.3$ years) $(p=0.311)$ in the group with mean ICP above $20 \mathrm{mmHg}$, though failed to reach significance (Zeiler et al., 2020d). Those patients in the group with mean ICP above $20 \mathrm{mmHg}$ had lower median $\mathrm{PbtO}_{2}$ of 22.1 (IQR: $18.2-26.2 \mathrm{mmHg}$ ) vs. 27 (IQR: 23.2-33.1 $\mathrm{mmHg}$ ) $(p=0.183)$ in those with mean ICP below $15 \mathrm{mmHg}$, though this failed to reach significance. As can be seen from the identified studies, they both made some reference to age in relation to this $\mathrm{PbtO}_{2}$, however it was somewhat vague. Males were predominant in these studies, but no major association was documented between the sexes. Table 1 provides a summary of 
TABLE 2 | Main representative studies evaluating link between NIRS, TDF-based CBF and CBFV with age/biological sex.

\begin{tabular}{|c|c|c|c|c|c|}
\hline References & $\begin{array}{l}\text { Monitoring } \\
\text { technique }\end{array}$ & $\begin{array}{c}\text { Number of } \\
\text { patients }\end{array}$ & $\begin{array}{c}\text { Patient } \\
\text { characteristics }\end{array}$ & Relevant results & Relevant conclusions \\
\hline \multicolumn{6}{|c|}{ NIRS } \\
\hline $\begin{array}{l}\text { Adatia et al. } \\
(2020)\end{array}$ & $\begin{array}{l}\text { - NIRS INVOS } \\
5100\end{array}$ & 104 & $\begin{array}{l}\text { - Severe brain injury; - GCS } \leq 8 \\
\text { Two groups of females were } \\
\text { studied: Mean and SD was } 6 \pm 3 \text { in } \\
\text { the Patients With Midline Shift } \\
\text { group and } 7 \pm 3 \text { in the Patients } \\
\text { Without Midline Shift group } \\
\text { (controls) }\end{array}$ & $\begin{array}{l}\text { Sex: } 43 \text { females in the group With } \\
\text { Midline Shift and } 6 \text { females in the } \\
\text { group Without Midline Shift } \\
\text { - Mean age: } 59 \pm 15 \text { years in the } \\
\text { group With Midline Shift and } \\
62 \pm 16 \text { years in the group Without } \\
\text { Midline Shift, } p=0.36\end{array}$ & $\begin{array}{l}\text { - Mean } \mathrm{rSO}_{2} \text {, median (IQR) in group } \\
\text { With Midline shift was } 64.7 \% \\
\text { (52-68.1\%) and in group Without } \\
\text { Midline } \mathrm{Shift} \text { was } 60.5 \% \\
(45.1-65.2 \%), p=0.39 \text { for both } \\
\text { groups } \\
\text { - It was noted that patients without } \\
\text { midline shift were older and had } \\
\text { lower mean } \mathrm{rSO}_{2}\end{array}$ \\
\hline $\begin{array}{l}\text { Adatia et al. } \\
(2018)\end{array}$ & $\begin{array}{l}\text { - NIRS INVOS } \\
5100\end{array}$ & 85 (16 with TBI) & $\begin{array}{l}\text { - Severe brain injury; - GCS } \leq 8 \\
\text { Data was for females in four } \\
\text { different temperature groups: } \\
\text { Median (IQR) GCS in No Change } \\
\text { group was } 3 \text { (3), Increasing and } \\
\text { Decreasing group was } 7 \text { (2) and } \\
\text { Fluctuating group was } 7 \text { (4) }\end{array}$ & $\begin{array}{l}\text { - Sex: females in No Change group } \\
=3 \text {, in Increasing group }=4 \text {, in } \\
\text { Decreasing group }=6 \text { and in } \\
\text { Fluctuating group }=27, p=0.40 \\
\text { - Median and IQR age: in No } \\
\text { Change group was } 54 \text { IQR } \\
31 \text { years, Increasing group was } \\
59 \text { IQR } 23 \text { years, Decreasing } \\
\text { group was } 61 \text { IQR } 21 \text { years and } \\
\text { Fluctuating group was } 60 \text { IQR } \\
18 \text { years, } p=0.38\end{array}$ & $\begin{array}{l}\text { - Mean } \mathrm{rSO}_{2} \text { with median IQR in No } \\
\text { Change group was } 66 \%(12 \%) \text {, } \\
\text { Increasing group was } 57 \%(16 \%) \text {, } \\
\text { Decreasing group was } 63 \%(8 \%) \\
\text { and Fluctuating group was } 17 \% \\
\text { (21\%), } p=0.13 \text { for all groups } \\
\text { - Highest } \mathrm{rSO}_{2} \text { was noted in the } \\
\text { youngest patients belonging to the } \\
\text { No Change group }\end{array}$ \\
\hline
\end{tabular}

$\mathrm{CBF}$

\begin{tabular}{|c|c|c|c|c|}
\hline $\begin{array}{l}\text { Dias et al. } \\
(2015)\end{array}$ & $\begin{array}{l}\text { - Parenchymal } \\
\text { thermal diffusion } \\
\text { probe }\end{array}$ & 18 & $\begin{array}{l}\text { - Severe TBI } \\
\text { - Patients were divided into two } \\
\text { groups } \\
\text { Median baseline GCS was } 6 \text { IQR } 3 \text {, } \\
\text { Median (IQR) in the } \\
\text { Cerebrovascular Reactivity (CVR) } \\
\text { Preserved PRx }<0.25 \text { group was } 7 \\
\text { (4) and CVR Impaired PRx }>0.25 \\
\text { group was } 4 \text { (2) }\end{array}$ & $\begin{array}{l}\text { - Sex: } 26 \text { females; } 16 \text { males } \\
\text { - Mean age: } 42 \text { SD } 16 \text { years } \\
15 \text { patients with mean age of } \\
40 \pm 16 \text { years were part of the } \\
\text { Cerebrovascular Reactivity (CVR) } \\
\text { Preserved PRx }<0.25 \text { group and } 3 \\
\text { patients with mean age of } \\
52 \pm 11 \text { years were part of the CVR } \\
\text { Impaired } P R x>0.25 \text { group }\end{array}$ \\
\hline
\end{tabular}

\begin{tabular}{|c|c|c|c|c|}
\hline $\begin{array}{l}\text { Dickman et al. } \\
\text { (1991) }\end{array}$ & $\begin{array}{l}\text { - Cortical thermal } \\
\text { diffusion probe }\end{array}$ & 12 & $\begin{array}{l}\text { - Moderate and severe TBI } \\
\text { - Mean GCS at admission was } 6 \\
\text { range } 4-12\end{array}$ & $\begin{array}{l}\text { - Sex: } 8 \text { males; } 4 \text { females } \\
\text { - Mean age: } 31 \text { range } 7-65 \text { years }\end{array}$ \\
\hline
\end{tabular}
- The 15 patients who were part of the Cerebrovascular Reactivity (CVR) Preserved PRx <0.25 group had mean CBF of $39.0 \pm 20.9 \mathrm{ml} /$ $100 \mathrm{~g} / \mathrm{min}$ and the 3 patients who were part of the CVR Impaired $\mathrm{PRx}>0.25$ group had mean CBF of $36.3 \pm 22.2 \mathrm{ml} / 100 \mathrm{~g} / \mathrm{min}, p$ 0.953 for both groups
- Patients in the impaired group were noted to be older and had lower CBF

- The following are CBF patterns seen in this study: A 25 year old female maintained normal CBF, 3 males and 1 female age range 30-65 years had reduced CBFs, 3 died and one had a vegetative outcome

4 males and 3 females age range 7-48 years had elevated CBFs, 5 died, 1 had mild cognitive deficits and 1 was in a persistent coma for 16 months after injury

CBFV

\begin{tabular}{|c|c|c|c|c|c|}
\hline $\begin{array}{l}\text { Czosnyka } \\
\text { et al. (2005) }\end{array}$ & $\begin{array}{l}\text { - Doppler } \\
\text { Ultrasound }\end{array}$ & $\begin{array}{l}\text { - } 358 \text { patients } \\
\text { total, } 237 \text { had } \\
\text { CBFV } \\
\text { monitoring }\end{array}$ & $\begin{array}{l}\text { - Mild to severe brain injury } \\
\text { - GCS scores ranged from 3-15 } \\
\text { - Mild to moderate; - GCS 9-15 }\end{array}$ & $\begin{array}{l}\text { - Sex: } 288 \text { males; } 60 \text { females } \\
\text { - Age range: 16-87 years }\end{array}$ & $\begin{array}{l}\text { - Blood flow velocity was not } \\
\text { dependent on age }(p=0.58) \\
\text { - No mention was made of a } \\
\text { relationship with patient sex } \\
\text { (Continued on following page) }\end{array}$ \\
\hline
\end{tabular}


TABLE 2 | (Continued) Main representative studies evaluating link between NIRS, TDF-based CBF and CBFV with age/biological sex.

\begin{tabular}{|c|c|c|c|c|c|}
\hline References & $\begin{array}{l}\text { Monitoring } \\
\text { technique }\end{array}$ & $\begin{array}{c}\text { Number of } \\
\text { patients }\end{array}$ & $\begin{array}{c}\text { Patient } \\
\text { characteristics }\end{array}$ & Relevant results & Relevant conclusions \\
\hline $\begin{array}{l}\text { Bouzat et al. } \\
\text { (2011) }\end{array}$ & $\begin{array}{l}\text { - Transcranial } \\
\text { Doppler (TCD) }\end{array}$ & 98 & $\begin{array}{l}\text { Two groups of patients were } \\
\text { studied: Initial GCS score in group } \\
\text { with No secondary neurological } \\
\text { deterioration (SND) was } 14 \text { (9-15) } \\
\text { and in the group with SND was } 13 \\
(10-15)\end{array}$ & $\begin{array}{l}\text { - Sex: } 64 \text { males and } 13 \text { females in } \\
\text { the group with No SND and } 20 \\
\text { males and } 1 \text { female in the group } \\
\text { with SND } \\
\text { - Age and range: } 34,15-84 \text { years } \\
\text { in the group with No SND and } 46 \\
\text { range } 20-80 \text { years in the group } \\
\text { with SND, } p=0.04\end{array}$ & $\begin{array}{l}\text { - Mean blood flow velocity (FVm) } \\
\text { was lower at } 31 \text { range } 18-60 \mathrm{~cm} / \mathrm{s} \\
\text { in the SND group as compared } \\
\text { to the No SND group where FVm } \\
\text { was higher at } 49 \text { range } 31-80 \mathrm{~cm} / \mathrm{s} \text {, } \\
p<0.01 \text { for both groups } \\
\text { - Patients in the SND were older and } \\
\text { had low FVm }\end{array}$ \\
\hline $\begin{array}{l}\text { Cardim et al. } \\
(2020)\end{array}$ & $\begin{array}{l}\text { - Transcranial } \\
\text { Color-Coded } \\
\text { Duplex (TCCD) }\end{array}$ & 95 & $\begin{array}{l}\text { - Severe TBI } \\
\text { - GCS ranged from 3-8 }\end{array}$ & $\begin{array}{l}\text { - Sex: } 70 \text { males; } 25 \text { females } \\
\text { - Age: Patients were older than } \\
18 \text { years and divided into } 3 \text { age } \\
\text { groups: group } 1 \text { was young } \\
\text { adults } 18-44 \text { years, group } 2 \text { was } \\
\text { middle-aged adults } 45-64 \text { years } \\
\text { and group } 3 \text { was older adults } \\
\text { above } 65 \text { years }\end{array}$ & $\begin{array}{l}\text { - No significant correlation was } \\
\text { found between CBFV and age } \\
\text { - Total FVm and median IQR in } \\
\text { males across all age groups was } \\
65.67 \text { ( } 58.41-71.67 \mathrm{~cm} / \mathrm{s}) \\
\text { and for females was } 71.67 \\
\text { (62.67-78.67 cm/s), } p \leq 0.05 \\
\text { for both groups } \\
\text { - There was a significant variation in } \\
\text { FVm between males and females } \\
\text { with females FVm higher in each } \\
\text { age group compared to males } \\
\text { - Also, FVm in the older group } 3 \\
\text { patients were lowest in both males } \\
\text { and females }\end{array}$ \\
\hline $\begin{array}{l}\text { Hu et al. } \\
(2008)\end{array}$ & - TCD & 30 & $\begin{array}{l}\text { - Moderate to severe } \\
\text { - Mean GCS was } 6 \text { range 3-13 }\end{array}$ & $\begin{array}{l}\text { - Sex: Data provided for two groups } \\
\text { of patients: in Brain Injury group - } \\
23 \text { males and } 7 \text { females and in the } \\
\text { Control group - } 8 \text { males and } 4 \\
\text { females } \\
\text { - Mean age: in Brain Injury group } \\
\text { was } 38 \pm 16 \text { years and in the } \\
\text { Control group was } \\
43.7 \pm 11.9 \text { years }\end{array}$ & $\begin{array}{l}\text { - In Brain Injury group mean CBFV } \\
\text { on the left was } 65.7 \pm 33.9 \mathrm{~cm} / \mathrm{s} \\
\text { and in Control group was } \\
56.5 \pm 19.8 \mathrm{~cm} / \mathrm{s} \\
\text { - In Brain Injury group mean CBFV } \\
\text { on the right was } 62.5 \pm 28.2 \mathrm{~cm} / \mathrm{s} \\
\text { and in Control group was } \\
57.4 \pm 16.1 \mathrm{~cm} / \mathrm{s} \\
\text { - CBFV was higher in the patients } \\
\text { than in controls and patients were } \\
\text { younger than controls }\end{array}$ \\
\hline
\end{tabular}

$\%=$ percentage, $C B F(s)=$ cerebral blood flow $(s), c m / s=$ centimeters per second, CVR, cerebrovascular reactivity; FVm, mean blood flow velocity, GCS, glasgow coma scale; IQR, interquartile range, $\mathrm{ml} / 100 \mathrm{~g} / \mathrm{min}=$ milliliters per $100 \mathrm{~g}$ per minute, NIRS, near infrared spectroscopy, $\mathrm{p}=\mathrm{p}$-value, PRx, pressure reactivity index, $r S O 2=$ regional cerebral oxygen saturations, SD, standard deviation; SND, secondary neurological deterioration; TBI, traumatic brain injury; TCD, transcranial Doppler; TCCD, Transcranial Color-Coded Duplex.

the available studies showing the relationship of this parameter with age and sex.

\section{ADVANCED CEREBRAL MONITORING IN TRAUMATIC BRAIN INJURY}

\section{Regional Cerebral Oxygen Saturations - Near Infrared Spectroscopy Measures}

NIRS is a non-invasive technique which utilizes light in the range $700-1,000 \mathrm{~nm}$ on the electromagnetic spectrum to monitor frontal cerebral oxy-hemoglobin and deoxy-hemoglobin concentration, as well as regional cerebral oxygen saturations $\left(\mathrm{rSO}_{2}\right)$ (Mathieu et al., 2020). Thresholds for outcome in TBI remain unclear at this time, though data suggests worse cerebral oxygen saturations, and duration of impairment, are linked to worse long-term outcome (Zweifel et al., 2010; Mathieu et al., 2020). Despite a recent systematic review on NIRS in TBI, there are limited studies available documenting the statistical association between age/biological sex and high-frequency NIRS measures in moderate/severe TBI. These limited studies demonstrated that older patients tended to have low $\mathrm{rSO}_{2}$ and suffer undesirable outcomes, though this was only a trend which failed to reach statistical significance (Adatia et al., 2018; Adatia et al., 2020). Adatia et al. showed that the younger patients, with a median age of 54 (IQR: 31$)$ years vs. 61 (IQR: 21$)$ years $(p=0.38)$, had the highest mean $\mathrm{rSO}_{2}$ of 66 (IQR: $\left.12 \%\right)$ vs. 63 (IQR: $\left.8 \%\right)(p=0.13)$ (Adatia et al., 2018). While in follow-up, Adatia et al. demonstrated that patients without midline shift were older, with mean age of $62 \pm 16$ years vs. $59 \pm 15$ years $(p=0.36$ ) (Adatia et al., 2020). In this follow-up work, older patients had lower median $\mathrm{rSO}_{2}$ of 60.5 (IQR: 45.1-65.2\%) compared to younger patients with $\mathrm{rSO}_{2}$ values of 64.7 (IQR: $52.0-68.1 \%$ ) ( $p=0.39$ ) (Adatia et al., 2020). There was not a clear breakdown of male vs. females. Table 2 provides a summary of selected large studies showing the relationship of this parameter with age and sex. 
TABLE 3 | Main representative studies evaluating link between PRx and cerebral compensatory reserve with age/biological sex.

\begin{tabular}{|c|c|c|c|c|c|}
\hline References & Monitoring technique & $\begin{array}{c}\text { Number of } \\
\text { patients }\end{array}$ & $\begin{array}{c}\text { Patient } \\
\text { characteristics }\end{array}$ & Relevant results & Relevant conclusions \\
\hline \multicolumn{6}{|c|}{ Cerebrovascular Reactivity } \\
\hline $\begin{array}{l}\text { Czosnyka } \\
\text { et al. (2008) }\end{array}$ & $\begin{array}{l}\text { - ICP: intraparenchymal probe } \\
\text { (Camino ICP transducer in } 12 \\
\text { patients and Codman ICP } \\
\text { Microsensors in } 566 \text { patients) or } \\
\text { via a ventricular drain and an } \\
\text { external pressure transducer } \\
\text { (34 patients) } \\
\text { - ABP: indwelling arterial catheter } \\
\text { in the radial artery }\end{array}$ & $\begin{array}{l}612 \text { total } \\
\text { patients, } 469 \\
\text { with PRx data }\end{array}$ & $\begin{array}{l}\text { - Severe TBI } \\
\text { - Median admission GCS was } 6 \\
\text { in both males and females }\end{array}$ & $\begin{array}{l}\text { - Sex: } 371 \text { males; } 98 \text { females } \\
\text { - Mean age: females } 34 \text { SD } \\
\text { 16.5 years } \\
\text { Males } 34 \text { SD } 17 \text { years }\end{array}$ & $\begin{array}{l}\text { - There was significantly worse } \\
\text { cerebrovascular pressure } \\
\text { reactivity in females compared } \\
\text { to males below } 50 \text { years; PRx } \\
\text { in males was } 0.044 \pm 0.031 \text { and } \\
\text { females was } 0.11 \pm 0.047, \\
p<0.05 \\
\text { - This was not reflected in } \\
\text { patients over } 50 \text { years } \\
\text { - Younger patients who showed } \\
\text { abnormal PRx of }>0.3 \text { had } \\
\text { intracranial hypertension (mean } \\
\text { ICP }>25 \text { mmHg), seen in } 60 \% \\
\text { females and } 20 \% \text { males } \\
(p<0.05 \text { ) }\end{array}$ \\
\hline $\begin{array}{l}\text { Adams et al. } \\
\text { (2017) }\end{array}$ & $\begin{array}{l}\text { - ICP: Intraparenchymal } \\
\text { microsensor (Codman) } \\
\text { - ABP: radial or femoral artery }\end{array}$ & $\begin{array}{l}601 \text { total } \\
\text { patients, } 556 \\
\text { with PRx data }\end{array}$ & $\begin{array}{l}\text { - Severe TBI } \\
\text { - Based on total cohort of } \\
\text { patients (601): best } \\
\text { preintubation GCS 3-8 in } 435 \\
\text { patients and 9-15 in } 166 \\
\text { patients } \\
\text { - Two groups of patients were } \\
\text { monitored } \\
\text { - Based on } 556 \text { patients with } \\
\text { PRx data: best preintubation } \\
\text { GCS in Functional Survivors } \\
\text { group was 3-8 in 329 patients } \\
\text { and 9-15 in 139 patients } \\
\text { In Fatal Outcome group was 3-8 } \\
\text { in } 71 \text { patients and 9-15 in 17 } \\
\text { patients }\end{array}$ & $\begin{array}{l}\text { - Sex: based on total cohort } \\
\text { of patients (601): } 464 \\
\text { males, } 137 \text { females } \\
\text { Based on } 556 \text { patients with } \\
\text { PRx data: Functional } \\
\text { Survivors group: } 360 \text { males, } \\
108 \text { females } \\
\text { Fatal Outcome group: } 68 \\
\text { males, } 20 \text { females } \\
\text { - Mean age: based on total } \\
\text { cohort of patients (601): } 39 \\
\text { SD } 17 \text { years } \\
\text { Based on } 556 \text { patients with } \\
\text { PRx data: Functional } \\
\text { Survivors group: } \\
38 \pm 16 \text { years } \\
\text { Fatal Outcome group: } \\
45 \pm 18 \text { years }\end{array}$ & $\begin{array}{l}\text { - Mean PRx and SD in Functional } \\
\text { Survivors group was } 0.05 \pm 0.15 \\
\text { a.u. and in the Fatal Outcome } \\
\text { group was } 0.16 \pm 0.21 \text { a.u., } \\
p<0.001 \\
\text { - Males were predominant in } \\
\text { both groups } \\
\text { - The Fatal Outcome group had } \\
\text { older patients with higher } \\
\text { mean PRx }\end{array}$ \\
\hline $\begin{array}{l}\text { Sorrentino } \\
\text { et al. (2012) }\end{array}$ & $\begin{array}{l}\text { - ICP: intraparenchymal } \\
\text { transducer (Codman) } \\
\text { - ABP: radial or dorsalis pedis } \\
\text { artery }\end{array}$ & 459 & $\begin{array}{l}\text { - Mild to severe TBI } \\
\text { - Median admission GCS was } 7 \\
\text { range } 3-15, \text { IQR } 5 \\
338 \text { patients had GCS } \leq 8 \text { and } \\
121 \text { patients had a GCS } \geq 9\end{array}$ & $\begin{array}{l}\text { - Sex: } 359 \text { males; } 100 \\
\text { females } \\
\text { - Median age: } 34, \text { IQR } \\
27 \text { years } \\
\text { - PRx survival threshold was } \\
0.25, p<0.001 \text { while } \\
\text { favorable outcome } \\
\text { threshold was } 0.05, p< \\
0.001 \\
\text { - No PRx threshold was } \\
\text { found for survival or } \\
\text { favorable outcome in } \\
\text { patients }>55 \text { years old } \\
\text { - PRx threshold for survival in } \\
\text { patients } \leq 55 \text { years was } 0.3 \text {, } \\
p<0.001 \text { and } 0, p<0.001 \\
\text { for favorable outcome } \\
\text { - PRx threshold for survival in } \\
\text { females was } 0.25,0.3, p< \\
0.001 \text { and for favourable } \\
\text { outcome was } 0.25,0.3, p= \\
0.026 \\
\text { - PRx threshold for survival in } \\
\text { males was } 0.3, p=0.002 \\
\text { and } 0, p<0.001 \text { for } \\
\text { favorable outcome }\end{array}$ & $\begin{array}{l}\text { - PRx threshold for survival was } \\
\text { higher in males than females } \\
\text { and for favorable outcome was } \\
\text { higher in females than males }\end{array}$ \\
\hline
\end{tabular}


TABLE 3 | (Continued) Main representative studies evaluating link between PRx and cerebral compensatory reserve with age/biological sex.

\begin{tabular}{|c|c|c|c|c|c|}
\hline References & Monitoring technique & $\begin{array}{c}\text { Number of } \\
\text { patients }\end{array}$ & $\begin{array}{c}\text { Patient } \\
\text { characteristics }\end{array}$ & Relevant results & Relevant conclusions \\
\hline $\begin{array}{l}\text { Zeiler et al. } \\
\text { (2018) }\end{array}$ & $\begin{array}{l}\text { - ICP: Intraparenchymal strain } \\
\text { gauge probe (Codman) } \\
\text { - ABP: radial or femoral arterial } \\
\text { lines attached to pressure } \\
\text { transducers }\end{array}$ & 358 & $\begin{array}{l}\text { - Moderate to severe TBI } \\
\text { - Two groups of patients were } \\
\text { monitored } \\
\text { Mean and median } \\
\text { GCS with SD/IQR for RAC < } \\
\text {-0.05 group was } 7(4-10) \text { and in } \\
\geq-0.05 \text { group was } 5(3-8.25) \\
\text { For RAC <-0.10 group } \\
\text { was } 7(4-10) \\
\text { and in } \geq-0.10 \\
\text { group was } 6 \\
\text { (3-8.25) }\end{array}$ & $\begin{array}{l}\text { - Mean/median age with SD/ } \\
\text { IQR: RAC < -0.05 group } \\
\text { was } 39.2(16.7) \text { years and } \\
\text { in } \geq 0.05 \text { group was } 50.6 \\
\text { (17.5) years, } p \text { value } \\
<0.0001 \text { for both groups } \\
\text { For RAC <-0.10 group was } \\
38.9(16.7) \text { years and in } \geq \\
\text {-0.10 group was } 49.7(17.0) \\
\text { years, } p \text { value }<0.0001 \text { for } \\
\text { both groups }\end{array}$ & $\begin{array}{l}\text { - A notable difference was seen } \\
\text { between age and APACHE } \\
\text { scores of those patients below } \\
\text { and above index thresholds; } \\
\text { increased age and APACHE } \\
\text { scores was seen in those } \\
\text { above the thresholds } \\
\text { - Of statistical significance was } \\
\text { patient's age with impaired } \\
\text { cerebrovascular reactivity } \\
\text { which showed high AUCs and } \\
\text { low p values } \\
\text { - The univariate logistic } \\
\text { regression analysis } \\
\text { showed generally increasing } \\
\text { values for AUC and } \\
p \text { values for age and } \\
\text { sex in relation to PRx } \\
\text { >0, } 0.25 \\
\text { and } 0.35 \\
\text { - Advancing age } \\
\text { was linked } \\
\text { to impaired } \\
\text { autoregulation }\end{array}$ \\
\hline $\begin{array}{l}\text { Czosnyka } \\
\text { et al. (2005) }\end{array}$ & $\begin{array}{l}\text { - ICP: intraparenchymal probe } \\
\text { (Camino ICP transducer in } 12 \\
\text { patients and Codman ICP } \\
\text { Microsensors } \\
\text { in } 346 \text { patients) } \\
\text { - ABP: obtained } \\
\text { invasively }\end{array}$ & 358 & $\begin{array}{l}\text { - Mild to severe TBI } \\
\text { - Initial GCS scores } \\
\text { ranged from 3-15, } \\
20 \% \text { patients had a GCS score } \\
\text { above } 8\end{array}$ & $\begin{array}{l}\text { - Sex: } 288 \text { males; } \\
60 \text { females } \\
\text { - Age range: } 16-87 \text { years }\end{array}$ & $\begin{array}{l}\text { - Study showed } \\
\text { that elderly people suffered } \\
\text { worse outcomes } \\
\text { post TBI } \\
\text { - PRx showed deterioration of } \\
\text { cerebrovascular autoregulation } \\
\text { and worsening of outcomes } \\
\text { with age } r=0.24, p=0.003\end{array}$ \\
\hline
\end{tabular}

\begin{tabular}{|c|c|c|c|c|c|}
\hline \multicolumn{6}{|c|}{ Cerebral Compensatory Reserve } \\
\hline $\begin{array}{l}\text { Zeiler et al. } \\
\text { (2018) }\end{array}$ & $\begin{array}{l}\text { - ICP: intraparenchymal strain } \\
\text { gauge probe } \\
\text { - ABP: radial or femoral arterial } \\
\text { lines attached to pressure } \\
\text { transducers }\end{array}$ & 358 & $\begin{array}{l}\text { - Moderate to severe TBI } \\
\text { - Median admission GCS was } 7 \\
\text { IQR 3-9 }\end{array}$ & $\begin{array}{l}\text { - Sex: } 272 \text { males; } 86 \text { females } \\
\text { - Mean age: } 40.6 \text { SD } \\
\text { 17.2 years }\end{array}$ & $\begin{array}{l}\text { - No difference was noted in } \\
\text { mean RAP variables among } \\
\text { males and females, } p>0.05 \\
\text { - There was no relationship } \\
\text { between RAP variables and } \\
\text { patient age, } p>0.05\end{array}$ \\
\hline $\begin{array}{l}\text { Zeiler et al. } \\
\text { (2019) }\end{array}$ & $\begin{array}{l}\text { - ICP: Intraparenchymal strain } \\
\text { gauge probe (Codman), } \\
\text { parenchymal fiber optic } \\
\text { pressure sensor or external } \\
\text { ventricular drain } \\
\text { - ABP: radial or femoral arterial } \\
\text { lines attached to pressure } \\
\text { transducers }\end{array}$ & 196 & $\begin{array}{l}\text { - Moderate to severe TBI } \\
\text { - Mean/median and SD or IQR } \\
\text { for admission GCS was } \\
\text { 8 } \pm 5-13\end{array}$ & $\begin{array}{l}\text { - Sex: } 150 \text { males; } 46 \text { females } \\
\text { - Mean/median age: } 46.6 \mathrm{SD} \\
19.7 \text { years }\end{array}$ & $\begin{array}{l}\text { - Mean/median RAP (+/- SD/ } \\
\text { IQR) was 0.614 } \\
\text { (0.206) a.u. and wICP was } 5.8 \\
\text { (7.9) mmHg } \\
\text { - High mean age and } \\
\text { compensatory-reserve- } \\
\text { weighted intracranial pressure } \\
\text { (wICP) was associated with } \\
\text { worse outcomes and this } \\
\text { considerable difference was } \\
\text { noted between both Alive/ } \\
\text { Dead and Favorable/ } \\
\text { Unfavorable outcome groups } \\
\text { - } p<0.0001 \text { for high mean age in } \\
\text { Alive/Dead group and } p= \\
\text { 0.001 for Favourable/ } \\
\text { Unfavourable outcome group } \\
\text { - } p<0.0001 \text { for wICP in Alive/ } \\
\text { Dead group and } p=0.002 \text { for } \\
\text { Favourable/Unfavourable } \\
\text { outcome group } \\
\text { (Continued on following page) }\end{array}$ \\
\hline
\end{tabular}


TABLE 3 | (Continued) Main representative studies evaluating link between PRx and cerebral compensatory reserve with age/biological sex.

\begin{tabular}{|c|c|c|c|c|c|}
\hline References & Monitoring technique & $\begin{array}{c}\text { Number of } \\
\text { patients }\end{array}$ & $\begin{array}{c}\text { Patient } \\
\text { characteristics }\end{array}$ & Relevant results & Relevant conclusions \\
\hline $\begin{array}{l}\text { Czosnyka } \\
\text { et al. (1996b) }\end{array}$ & $\begin{array}{l}\text { - ICP: Camino transducer or } \\
\text { subdural catheter } \\
\text { - ABP: radial or dorsalis pedis } \\
\text { artery }\end{array}$ & 56 & $\begin{array}{l}\text { - Severe TBI } \\
\text { - Mean GCS was } \\
6 \text { range } 3-13\end{array}$ & $\begin{array}{l}\text { - Sex: } 40 \text { males } \\
16 \text { females } \\
\text { - Mean age: } 36 \text { range } \\
\text { 6-75 years }\end{array}$ & $\begin{array}{l}\text { - There was no overall } \\
\text { correlation made about this } \\
\text { parameter with age and sex, } \\
\text { but three specific examples } \\
\text { were given where patients died } \\
\text { from uncontrollable intracranial } \\
\text { hypertension } \\
\text { - In these cases, RAP either } \\
\text { dropped from around +1 to } 0 \\
\text { or negative values } \\
\text { - Patients: } 18 \text { year old, GCS } 3 \text { on } \\
\text { admission and RAP decreased } \\
\text { toward } 0 \text { and time average RAP } \\
\text { became negative; } 35 \text { year old } \\
\text { male, GCS } 3 \text { on admission, RAP } \\
\text { decreased to } 0 \text { and } 15 \text { year old } \\
\text { male, GCS } 3 \text {, RAP } 0\end{array}$ \\
\hline
\end{tabular}

ABP, arterial blood pressure; APACHE, acute physiology and chronic health evaluation; AUC, area under the ROC, curve; ICP, intracranial pressure; GCS, glasgow coma scale; GOS, glasgow outcome scale; $I Q R$, interquartile range, $\mathrm{p}=\mathrm{p}$-value, $P R x$, pressure reactivity index, $\%=$ percentage, $R O C$, receiver operating characteristic curve, $r=$ correlation coefficient, $R A P$ $=(R$-correlation, $A$ - pulse amplitude of ICP, $P$ - intracranial pressure), SD, standard deviation; TBI, traumatic brain injury; wICP, compensatory-reserve-weighted intracranial pressure.

The role of age and biologic sex in cerebral oxygen saturation, as measured by NIRS, has been more extensively examined outside the context of TBI. A recent study examined how rSO2 values differed by age and sex in a cohort of 1,616 adults undergoing cardiac interventions. They found that younger patients (18-49 years old) had significantly higher rSO2 values than middle-aged (50-74 years of age; $67 \%$ [95\% CI 59-74\%] vs. $63 \%$ [95\%CI 56-69\%], $p<0.001)$. Similarly, middle-aged individuals had higher cerebral oxygen saturations than elderly patients ( $>75$ years old; $63 \%$ [95\%CI 56-69] vs. $60 \%$ [95\%CI 55-66\%], $p<0.001)$. Males were also found to have significantly higher $\mathrm{rSO} 2$ values than females $(65 \%$ [95\%CI $58-70 \%]$ vs. $58 \%$ [95\%CI 52-63\%]) and while males had significantly higher hemoglobin values and were younger in this cohort, the significant effect of biological sex remained following multiple linear regression analysis accounting for these differences (Robu et al., 2020). In contrast, a longitudinal study of 3,110 healthy individuals over the age of 50 found that cerebral oxygenation was lower in males than females, when measured by NIRS. However, cerebral saturation values were found to also decrease with age (Newman et al., 2020).

\section{Cerebral Blood Flow and Flow Velocities - Thermal Diffusion and Transcranial Doppler Monitoring}

Thermal diffusion flowmetry (TDF) is a technique employed via the use of a cortical or parenchymal probe to monitor CBF, by evaluating the power needed to sustain a temperature difference between a proximal and distal thermistor (Rosenthal et al., 2011). Such devices have seen limited use in the moderate/severe TBI literature, given expertise and cost associated with their use (Mathieu et al., 2019a). As such, when objectively evaluating the link between age/biological sex and high-frequency TDF-based CBF, there are only a few studies available (Dickman et al., 1991; Dias et al., 2015). In the small studies evaluating its use in TBI, low CBF measures have been correlated with worse outcomes. Furthermore, these works demonstrated that older patients tended to have low CBF and suffer undesirable outcomes. Dias et al. showed that patients with preserved cerebrovascular reactivity (measured through pressure reactivity index value of $<0.25)$ were younger with mean age of $40 \pm 16$ years vs. $52 \pm 11$ years $(p=0.173)$ in those with impaired cerebrovascular reactivity (Dias et al., 2015). In this study, older patients in the impaired cerebrovascular reactivity group had lower mean $\mathrm{CBF}$ of $36.3 \pm 22.2 \mathrm{ml} / 100 \mathrm{~g} / \mathrm{min}$, compared to $39.0 \pm 20.9 \mathrm{ml} / 100 \mathrm{~g} / \mathrm{min}(p=$ 0.953 ) in the younger group of patients, though this failed to reach significance (Dias et al., 2015). The second study referenced gave specific patient examples without reporting $p$ values (Dickman et al., 1991). No major association was made between the sexes.

Aside from direct CBF measurement, TCD can be utilized to provide surrogate assessment of flow. TCD employs the use of ultrasound waves to insonate the basal cerebral arteries and assess CBFV non-invasively through Doppler frequency shift in the reflected signal, based on blood flow velocity in the insonated artery (Aaslid et al., 1982). Again, as with TDF, the requirement for technical expertise has limited its use in routine TBI monitoring. Low CBFV has been documented to be associated with worse long-term outcome in moderate/severe TBI populations (Czosnyka et al., 1996a; Budohoski et al., 2012; Czosnyka et al., 2005). As with the other monitoring modalities described above, there exists limited data in moderate/severe TBI patients on the association between CBFV and age/biological sex. The main studies have demonstrated that older patients tended to have low CBFV and suffer undesirable outcomes (Czosnyka et al., 2005; Bouzat et al., 2011; Cardim et al., 2020; Hu et al., 2008). This was seen in the study by Bouzat et al., where older vs. younger patients (median age of 46 (IQR: 20-80 years) vs. 34 (IQR: $15-84$ years), $p=0.04$ ) had lower mean CBFV of 31 (range: $18-60 \mathrm{~cm} / \mathrm{s})$ vs. 49 (range: $31-80 \mathrm{~cm} / \mathrm{s})(p<0.01)$, respectively 

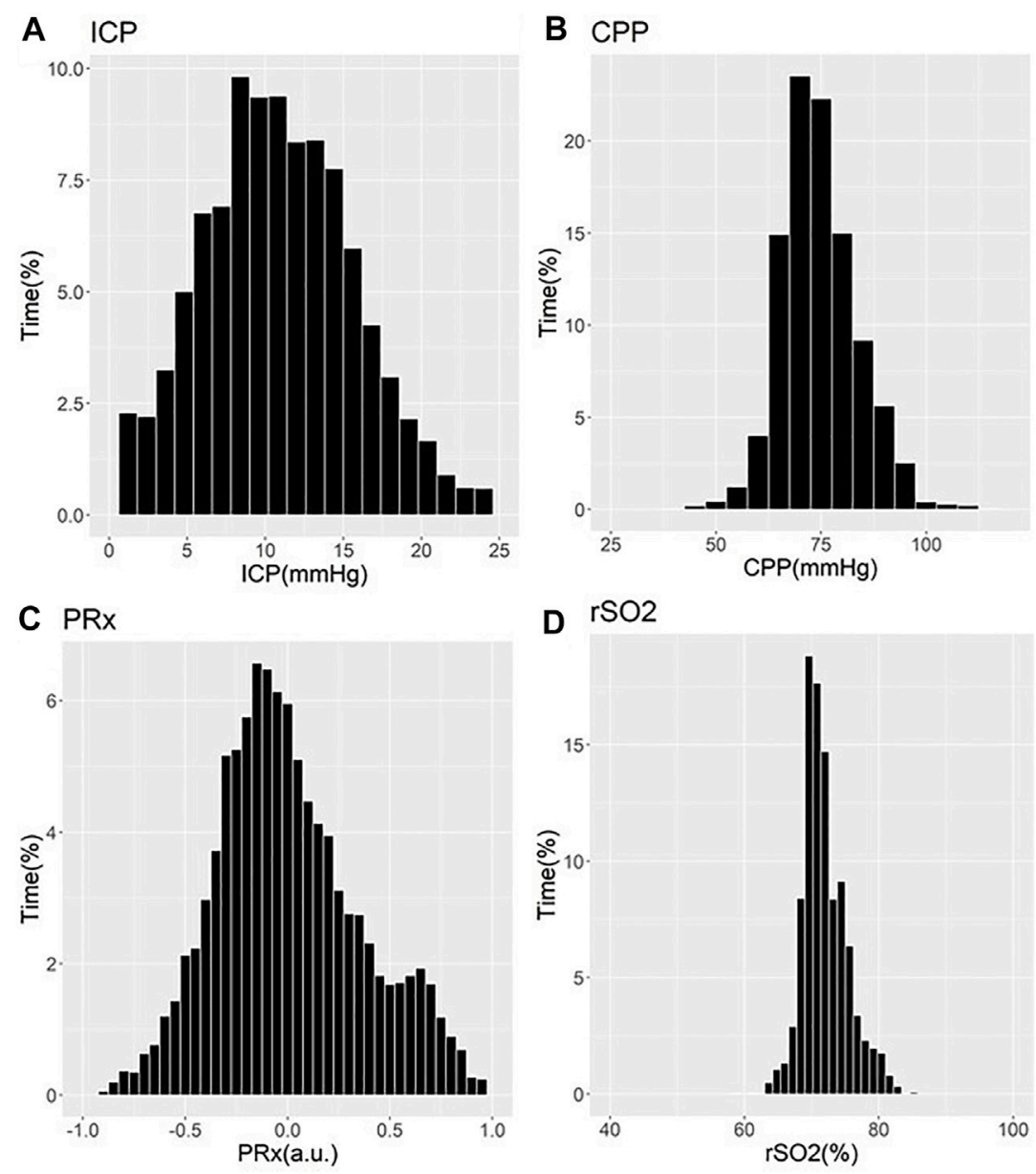

FIGURE 1 | Example of Cerebral Physiology in Severe TBI - 24 Year Old Patient - First 72 Hours of ICU Stay. a. u. = arbitrary units, CPP = cerebral perfusion pressure, $\mathrm{ICP}=$ intracranial pressure, $\mathrm{ICU}=$ intensive care unit, $\mathrm{mmHg}=$ millimeters of Mercury, $\mathrm{MAP}=$ mean arterial pressure, $\mathrm{PRx}=$ pressure reactivity index (correlation between slow-wave of ICP and MAP), $\mathrm{rSO}_{2}=$ regional cerebral oxygen levels (Rt Frontal). Panel (A) = histogram of ICP and \% time of recorded physiology, Panel (B) = histogram of CPP and \% time of recorded physiology, Panel (C) $=$ histogram of PRx and \% time of recorded physiology, Panel (D) $=$ histogram of $r S \mathrm{O}_{2}$ and $\%$ time of recorded physiology.

(Bouzat et al., 2011). Cardim et al., showed that older males had the lowest median FVm of 63 (IQR: $57.59-74.83 \mathrm{~cm} / \mathrm{s}$ ) vs. 69.33 (IQR: $65.33-72.67 \mathrm{~cm} / \mathrm{s}$ ) for females $(p \leq 0.05)$ (Cardim et al., 2020). Furthermore, $\mathrm{Hu}$ et al. described that mean CBFV was higher in patients (e.g., $65.7 \pm 33.9 \mathrm{~cm} / \mathrm{s}$ on left side of brain compared to $56.5 \pm 19.8 \mathrm{~cm} / \mathrm{s}$ on left side of brain for controls) who were younger than in controls (mean age and SD of patients were $38 \pm 16$ years and controls were $43.7 \pm 11.9$ years) (Hu et al., 2008). In contrast, Czosnyka et al. commented that CBFV may be independent of age, but required further investigation (Czosnyka et al., 2005). Table 2 provides a summary of large representative studies showing the relationship between TDF-based CBF and TCD-based CBFV, with age and sex. Outside of TBI, trends in FV and PI as measured by TCD have been identified based on age and sex. One study of 1720 healthy participants found that FVm, FVs, and FVd all decreased significantly with age while PI increased with age. Over the entire cohort, FVm, FV,s and
FVd were lower in males than females (Bakker et al., 2004). Similarly, in a cohort of 524 healthy subjects, FV in the MCA were found to decrease with age in both males and females. Notably, the rate of decline was significantly greater in females than males, indicating a sex-specific trajectory to the reduction in FV with age (Alwatban et al., 2021).

\section{DERIVED CEREBROVASCULAR METRICS IN TBI}

\section{Cerebrovascular Reactivity Monitoring - The Pressure Reactivity Index - "PRx"}

Cerebrovascular reactivity monitoring refers to the continuous assessment of cerebral autoregulation, through assessing the response in slow-wave vasogenic fluctuations of a measure of $\mathrm{CBF} /$ cerebral blood volume $(\mathrm{CBV})$, to changes in a driving 

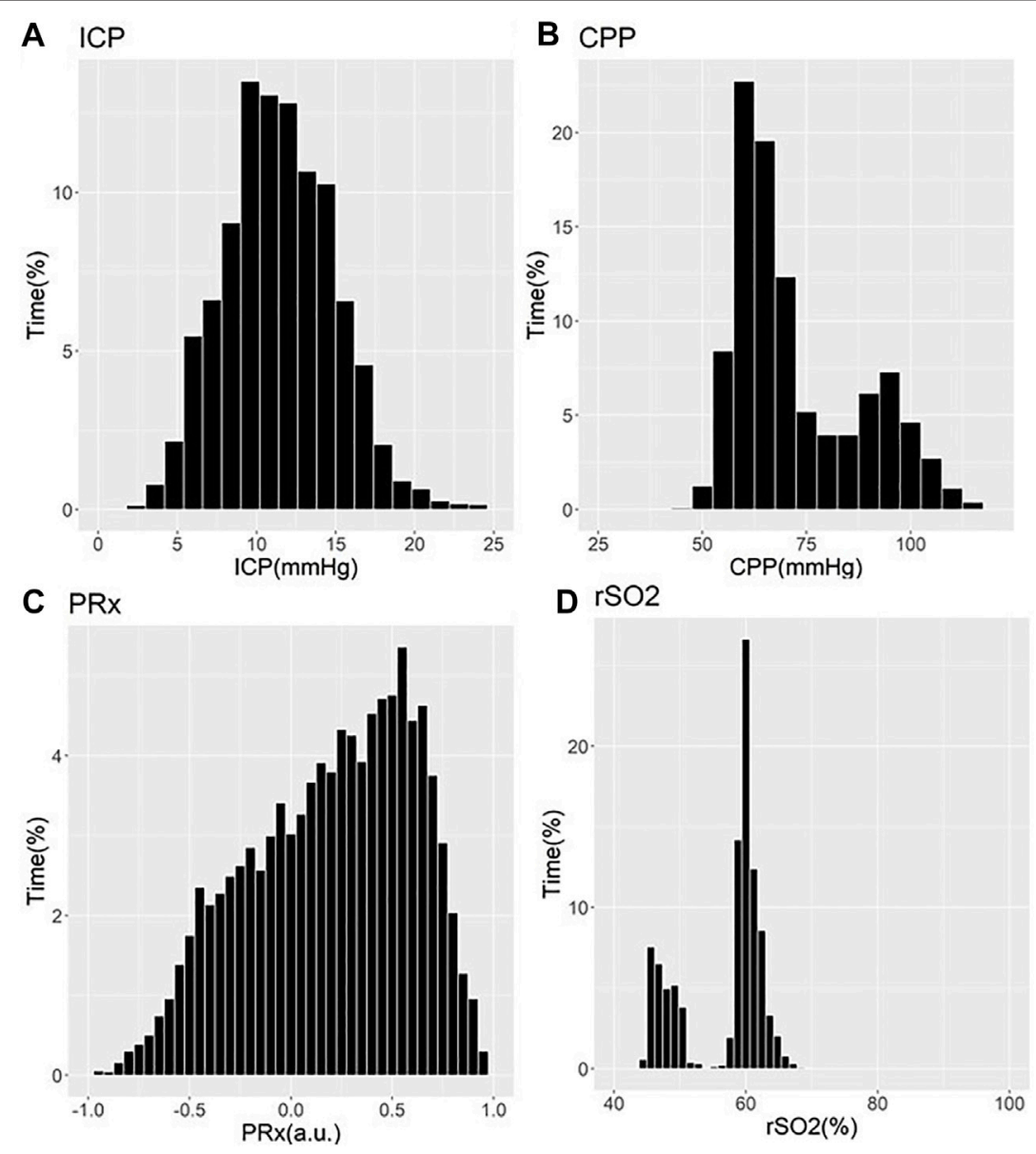

FIGURE 2 | Example of Cerebral Physiology in Severe TBI - 67 Year Old Patient-First 72 Hours of ICU Stay. a. u. = arbitrary units, CPP = cerebral perfusion pressure, $\mathrm{ICP}=$ intracranial pressure, $\mathrm{ICU}=$ intensive care unit, $\mathrm{mmHg}=$ millimeters of Mercury, $\mathrm{MAP}=\mathrm{mean}$ arterial pressure, $\mathrm{PRx}=$ pressure reactivity index (correlation between slow-wave of ICP and MAP), $\mathrm{rSO}_{2}=$ regional cerebral oxygen levels (Rt Frontal). Panel (A) = histogram of ICP and \% time of recorded physiology, Panel (B) $=$ histogram of CPP and \% time of recorded physiology, Panel $(\mathbf{C})=$ histogram of PRx and \% time of recorded physiology, Panel (D) $=$ histogram of $r S \mathrm{O}_{2}$ and $\%$ time of recorded physiology.

pressure for CBF, such as MAP or CPP (Czosnyka et al., 1997; Zeiler et al., 2017d). Pressure reactivity index (PRx) is the most widely described continuous cerebrovascular reactivity measure in TBI monitoring, and is derived from the moving Pearson correlation coefficient between slow-waves of ICP and MAP, with negative values representing "intact" cerebral autoregulation, and positive values denoting "impaired" autoregulation (Czosnyka et al., 1997; Sorrentino et al., 2012). Various single and multi-center studies have documented the strong association between impaired cerebrovascular reactivity and outcomes in moderate/severe TBI (Zeiler et al., 2019a; Donnelly et al., 2019; Bennis et al., 2020). Similarly, PRx is one of the few multi-modal monitoring metrics which has evidence to support its added prognostic value beyond that of ICP, in models adjusting for baseline admission characteristics (Zeiler et al., 2018a; Zeiler et al., 2019a; Bennis et al., 2020). Again, most studies on PRx do not comment directly on the association between cerebrovascular reactivity and age/biological sex. We have highlighted the main and largest such studies on PRx in Table 3.
These works have demonstrated that older patients tended to suffer undesirable outcomes, with trends towards worse cerebrovascular reactivity metrics (Czosnyka et al., 2005; Czosnyka et al., 2008; Sorrentino et al., 2012; Zeiler et al., 2018b; Zeiler et al., 2019a). Three studies showed that older patients with high PRx suffered fatal outcomes. Statistical significance was commented on in two of these PRx studies, one by Czosnyka et al. (2005) and one by Adams et al. (2017) In the Czosnyka et al. (2005) study, it is seen that PRx degraded with increasing age from a mean of $0.01 \pm 0.13 \mathrm{a}$. u. to $0.05 \pm 0.12 \mathrm{a}$. u. $(p=0.03)$ (Czosnyka et al., 2005). In the Adams et al. study, mean $\mathrm{PRx}$ of patients in the functional survivors group was lower compared to patients in the fatal outcome group, with results of $0.05 \pm 0.15$ a. u. vs. $0.16 \pm 0.21$ a. u. $(p<0.001$ ), respectively (Adams et al., 2017). In this study, patients in the functional survivors group were younger with a mean age of $38 \pm 16$ years vs. patients in the Fatal Outcome group who were older at $45 \pm 18$ years $(p<0.001)$. Sorrentino et al. found that when evaluating PRx thresholds for survival, $\mathrm{PRx}$ was lower in females at $0.25 \mathrm{a}$. u. vs. males at $0.3 \mathrm{a}$. u. 
TABLE 4 | Main representative studies evaluating link between standard CMD analytes and age/biological sex.

\begin{tabular}{|c|c|c|c|c|c|}
\hline References & CMD analyte & $\begin{array}{c}\text { Number of } \\
\text { patients }\end{array}$ & $\begin{array}{c}\text { Patient } \\
\text { characteristics }\end{array}$ & Relevant results & Relevant conclusions \\
\hline \multicolumn{6}{|c|}{ Glucose } \\
\hline $\begin{array}{l}\text { Stein et al. } \\
(2012)\end{array}$ & $\begin{array}{l}\text { - Microdialysis } \\
\text { catheter CMA } 70 \\
\text { - Perfused using } \\
\text { microdialysis } \\
\text { pump CMA } 106 \\
\text { - Microdialysis } \\
\text { analyzer } \\
\text { CMA } 600\end{array}$ & 89 & $\begin{array}{l}\text { - Moderate to severe TBI } \\
\text { - Median GCS was } 6.5 \\
55 \text { patients had a GCS between } 3 \\
\text { and } 8 \text { and } 34 \text { patients had a } \\
\text { GCS 9-12 } \\
\text { Two groups of patients } \\
\text { were studied: median and } \\
\text { IQR GCS in the Favourable } \\
\text { Outcome group was } 9 \text { (7.3-12.5) } \\
\text { and in the } \\
\text { Unfavourable Outcome group } \\
\text { was } 6 \text { (3-10.8) }\end{array}$ & $\begin{array}{l}\text { - Sex: } 74 \text { males; } 15 \text { females } \\
\text { - Mean age: } 46.4 \text { years } \\
\text { Median age and IQR in Favourable } \\
\text { 6-months Outcome group was } \\
\text { 32.5, 26.3-45 years and in the } \\
\text { Unfavourable 6-months Outcome } \\
\text { group was 50.5, 38.3-62.0 years }\end{array}$ & $\begin{array}{l}\text { - Median and IQR range for glucose } \\
\text { in the Favourable } 6 \text {-months } \\
\text { Outcome group was } 1.3 \text {, } \\
\text { 0.9-3.1 mmol/L and in the } \\
\text { Unfavourable } 6 \text {-months Outcome } \\
\text { group was } 0.9,0.6-1.5 \mathrm{mmol} / \mathrm{L}, \\
p \text { value } 0.061 \text { for both groups } \\
\text { - Poor outcomes were seen in older } \\
\text { patients and those with lower } \\
\text { glucose levels }\end{array}$ \\
\hline $\begin{array}{l}\text { Kurtz et al. } \\
\text { (2013) }\end{array}$ & $\begin{array}{l}\text { - Microdialysis } \\
\text { catheter CMA } 70 \\
\text { - Perfused using } \\
\text { microdialysis } \\
\text { pump CMA } 106 \\
\text { - Microdialysis } \\
\text { analyzer CMA } 600\end{array}$ & 46 & $\begin{array}{l}\text { - Moderate to severe brain injury } \\
\text { - Median age was } 55 \text { IQR } \\
\text { 42-64 years with } 27 \text { females } \\
\text { and } 19 \text { males } \\
\text { - Median GCS and IQR was 7,5-9 }\end{array}$ & $\begin{array}{l}\text { - Sex: } 27 \text { females } \\
19 \text { males } \\
\text { - Median age: 55 IQR 42-64 years }\end{array}$ & $\begin{array}{l}\text { - Median glucose was } 0.8 \text { IQR } \\
\text { 0.4-1.3 mmol/L } \\
\text { - Levels were low and linked to } \\
\text { cerebral metabolic distress and } \\
\text { increased mortality, } p<0.001\end{array}$ \\
\hline \multicolumn{6}{|c|}{ Glycerol } \\
\hline $\begin{array}{l}\text { Stein et al. } \\
(2012)\end{array}$ & $\begin{array}{l}\text { - Microdialysis } \\
\text { catheter CMA } 70 \\
\text { - Perfused using } \\
\text { microdialysis } \\
\text { pump CMA } 106 \\
\text { - Microdialysis } \\
\text { analyzer } \\
\text { CMA } 600\end{array}$ & 89 & $\begin{array}{l}\text { - Moderate to severe TBI } \\
\text { - Median GCS was } 6.5 \\
55 \text { patients had a GCS between } 3 \\
\text { and } 8 \text { and } 34 \text { patients had a GCS } \\
\text { 9-12; Two groups of patients } \\
\text { were studied: median and IQR } \\
\text { GCS in the Favourable Outcome } \\
\text { group was } 9 \text { (7.3-12.5) and in the } \\
\text { Unfavourable Outcome group } \\
\text { was } 6 \text { (3-10.8) }\end{array}$ & $\begin{array}{l}\text { - Sex: } 74 \text { males; } 15 \text { females } \\
\text { - Mean age: } 46.4 \text { years } \\
\text { Median age and IQR in Favourable } \\
\text { 6-months Outcome group was } \\
\text { 32.5, 26.3-45 years and in the } \\
\text { Unfavourable 6-months Outcome } \\
\text { group was 50.5, 38.3-62.0 years }\end{array}$ & $\begin{array}{l}\text { - Median and IQR for glycerol in the } \\
\text { Favourable 6-months Outcome } \\
\text { group was } 65.5,49.1-96.9 \\
\mu \text { mol/L and in the Unfavourable } \\
6 \text {-months Outcome group was } \\
63.7,42.3-124.6 \mu \mathrm{mol} / \mathrm{L}, p \text { value } \\
\text { 0.998 for both groups } \\
\text { - Poor outcomes were seen in older } \\
\text { patients with lower levels }\end{array}$ \\
\hline $\begin{array}{l}\text { Mellergård } \\
\text { et al. (2012) }\end{array}$ & $\begin{array}{l}\text { - Microdialysis } \\
\text { catheters } \\
\text { CMA } 71 \\
\text { - Perfused using } \\
\text { microdialysis } \\
\text { pump CMA } 106 \\
\text { - Microdialysis } \\
\text { analyzer } \\
\text { CMA } 600\end{array}$ & 69 & $\begin{array}{l}\text { - Severe TBI } \\
\text { - Glasgow Outcome Scale (GOS) } \\
\text { scores: } 21 \text { patients with a score } \\
\text { of } 1,1 \text { with a score of } 2,11 \text { with } \\
\text { a score of } 3,8 \text { with a score of } 4 \text {, } \\
16 \text { with a score of } 5 \text { and } 12 \text { with } \\
\text { an unknown score }\end{array}$ & $\begin{array}{l}\text { - Sex: } 48 \text { males; } 21 \text { females } \\
\text { - Mean age: } 45.9 \text { years }\end{array}$ & $\begin{array}{l}\text { - Glycerol in different age groups } \\
\text { was studied: in patients }<25 \text { years } \\
\text { was } 63.8 \pm 4.40 \mu \mathrm{mol} / \mathrm{L} \text {, } \\
25-45 \text { years was } 55.9 \pm 1.16 \mu \mathrm{mol} / \\
\mathrm{L}, 45-65 \text { years was } \\
88.4 \pm 2.81 \mu \mathrm{mol} / \mathrm{L} \text { and } \\
>65 \text { years was } 252 \pm 15.7 \mu \mathrm{mol} / \mathrm{L} \text {, } \\
p<0.0001 \\
\text { - Older patients had increased levels } \\
\text { and suffered poor outcomes }\end{array}$ \\
\hline
\end{tabular}

Glutamate

\begin{tabular}{|c|c|c|c|c|c|}
\hline $\begin{array}{l}\text { Chamoun } \\
\text { et al. (2010) }\end{array}$ & $\begin{array}{l}\text { - Microdialysis } \\
\text { probe CMA } 70 \\
\text { - Microdialysis } \\
\text { analyzer } \\
\text { CMA } 600\end{array}$ & 165 & $\begin{array}{l}\text { - Severe TBI } \\
\text { - GCS score ranged from 3-15 }\end{array}$ & $\begin{array}{l}\text { - Sex: } 141 \text { males; } 24 \text { females } \\
\text { - Mean age: } 36.6 \pm 14.8 \text { years }\end{array}$ & $\begin{array}{l}\text { - Patients with an average glutamate } \\
\text { level }>20 \mu \mathrm{mol} / L \text { had a higher } \\
\text { mortality rate } p=0.08 ; 76 \text { patients } \\
\text { fell in this category } \\
\text { - There was no correlation between } \\
\text { early glutamate levels and age }\end{array}$ \\
\hline $\begin{array}{l}\text { Stein et al. } \\
(2012)\end{array}$ & $\begin{array}{l}\text { - Microdialysis } \\
\text { catheter CMA } 70 \\
\text { - Perfused using } \\
\text { microdialysis } \\
\text { pump CMA } 106 \\
\text { - Microdialysis } \\
\text { analyzer } \\
\text { CMA } 600\end{array}$ & 89 & $\begin{array}{l}\text { - Moderate to severe TBI } \\
\text { - Median GCS was } 6.5 \\
55 \text { patients had a GCS between } 3 \\
\text { and } 8 \text { and } 34 \text { patients had a } \\
\text { GCS 9-12 } \\
\text { Two groups of patients were studied: } \\
\text { median and IQR GCS in the } \\
\text { Favourable Outcome group was } 9 \\
\text { (7.3-12.5) and in the Unfavourable } \\
\text { Outcome group was } 6 \text { (3-10.8) }\end{array}$ & $\begin{array}{l}\text { - Sex: } 74 \text { males; } 15 \text { females } \\
\text { - Mean age: } 46.4 \text { years } \\
\text { Median age and IQR in Favourable } \\
\text { 6-months Outcome group was } \\
\text { 32.5, 26.3-45 years and in the } \\
\text { Unfavourable 6-months Outcome } \\
\text { group was 50.5, 38.3-62.0 years }\end{array}$ & $\begin{array}{l}\text { - Median and IQR for glutamate in } \\
\text { the Favourable } 6 \text {-months } \\
\text { Outcome group was } 3.8, \\
\text { 3.3-6.4 } \mu \text { mol/L and in the } \\
\text { Unfavourable } 6 \text {-months Outcome } \\
\text { group was } 8.8,5.8-15.7 \mu \mathrm{mol} / \mathrm{L} \text {, } \\
p \text { value } 0.027 \text { for both groups } \\
\text { - Poor outcomes were seen in older } \\
\text { patients with higher levels }\end{array}$ \\
\hline
\end{tabular}


TABLE 4 | (Continued) Main representative studies evaluating link between standard CMD analytes and age/biological sex.

\begin{tabular}{|c|c|c|c|c|c|}
\hline References & CMD analyte & $\begin{array}{c}\text { Number of } \\
\text { patients }\end{array}$ & $\begin{array}{c}\text { Patient } \\
\text { characteristics }\end{array}$ & Relevant results & Relevant conclusions \\
\hline $\begin{array}{l}\text { Mellergård } \\
\text { et al. (2012) }\end{array}$ & $\begin{array}{l}\text { - Microdialysis } \\
\text { catheters } \\
\text { CMA } 71 \\
\text { - Perfused using } \\
\text { microdialysis } \\
\text { pump CMA } 106 \\
\text { - Microdialysis } \\
\text { analyzer } \\
\text { CMA } 600\end{array}$ & 69 & $\begin{array}{l}\text { - Severe TBI } \\
\text { - Glasgow Outcome Scale (GOS) } \\
\text { scores: } 21 \text { patients with a score } \\
\text { of } 1,1 \text { with a score of } 2,11 \text { with } \\
\text { a score of } 3,8 \text { with a score of } 4 \text {, } \\
16 \text { with a score of } 5 \text { and } 12 \text { with } \\
\text { an unknown score }\end{array}$ & $\begin{array}{l}\text { - Sex: } 48 \text { males; } 21 \text { females } \\
\text { - Mean age: } 45.9 \text { years }\end{array}$ & $\begin{array}{l}\text { - Glutamate in patients }<25 \text { years } \\
\text { was } 21.2 \pm 0.94 \mathrm{mmol} / \mathrm{L} \text {, } \\
25-45 \text { years was } \\
15.8 \pm 0.42 \mathrm{mmol} / \mathrm{L}, 45-65 \text { years } \\
\text { was } 41.0 \pm 2.05 \mathrm{mmol} / \mathrm{L} \text { and } \\
>65 \text { years was } 92.2 \pm 6.82 \mathrm{mmol} / \mathrm{L} \\
p<0.0001 \\
\text { - Older patients had increased levels } \\
\text { and suffered poor outcomes }\end{array}$ \\
\hline
\end{tabular}

Lactate and Pyruvate

\begin{tabular}{lllll}
\hline Clausen et al. & - Microdialysis & 151 total, 139 had & - Severe TBI & - Sex: 113 males \\
(2005) & probe CMA 20 & Microdialysis & - GCS was 3-8 at admission & 38 females \\
& - Microdialysis & monitoring & & - Mean age and SD was \\
& analyzer & & $35.5 \pm 16.9$ years \\
& CMA 600 & &
\end{tabular}

\begin{tabular}{|c|c|c|c|c|c|}
\hline $\begin{array}{l}\text { Stein et al. } \\
\text { (2012) }\end{array}$ & $\begin{array}{l}\text { - Microdialysis } \\
\text { catheter CMA } 70 \\
\text { - Perfused using } \\
\text { microdialysis } \\
\text { pump CMA } 106 \\
\text { - Microdialysis } \\
\text { analyzer } \\
\text { CMA } 600\end{array}$ & 89 & $\begin{array}{l}\text { - Moderate to severe TBI } \\
\text { - Median GCS was } 6.5 \\
55 \text { patients had a GCS between } 3 \\
\text { and } 8 \text { and } 34 \text { patients had a } \\
\text { GCS 9-12 } \\
\text { Two groups of patients were } \\
\text { studied: median and IQR GCS in } \\
\text { the Favourable Outcome group } \\
\text { was } 9 \text { (7.3-12.5) and in the } \\
\text { Unfavourable Outcome group } \\
\text { was } 6 \text { (3-10.8) }\end{array}$ & $\begin{array}{l}\text { - Sex: } 74 \text { males } \\
15 \text { females } \\
\text { - Mean age: } 46.4 \text { years } \\
\text { Median age and IQR in Favourable } \\
6 \text {-months Outcome group was } \\
32.5,26.3-45 \text { years and in the } \\
\text { Unfavourable 6-months Outcome } \\
\text { group was } 50.5,38.3-62.0 \text { years }\end{array}$ & $\begin{array}{l}\text { - Median and IQR for lactate in the } \\
\text { Favourable 6-months Outcome } \\
\text { group was } 1.8,1.5-3.0 \mathrm{mmol} / \mathrm{L} \\
\text { and in the Unfavourable 6-months } \\
\text { Outcome group was } 2.7, \\
\text { 1.5-4.3 mmol/L, } p \text { value } 0.132 \text { for } \\
\text { both groups } \\
\text { - Poor outcomes were seen in older } \\
\text { patients with higher levels } \\
\text { - Median and IQR for pyruvate in the } \\
\text { Favourable 6-months Outcome } \\
\text { group was } 78.7,51.3-117.5 \mu \mathrm{mol} / \\
\text { L and in the Unfavourable } 6- \\
\text { months Outcome group was } 77.9 \text {, } \\
\text { 49.9-121.8 } \mu \text { mol/L, } p \text { value } 0.978 \\
\text { - Poor outcomes were seen in older } \\
\text { patients with lower levels }\end{array}$ \\
\hline
\end{tabular}

(Continued on following page) 
TABLE 4 | (Continued) Main representative studies evaluating link between standard CMD analytes and age/biological sex.

\begin{tabular}{|c|c|c|c|c|c|}
\hline References & CMD analyte & $\begin{array}{c}\text { Number of } \\
\text { patients }\end{array}$ & $\begin{array}{c}\text { Patient } \\
\text { characteristics }\end{array}$ & Relevant results & Relevant conclusions \\
\hline $\begin{array}{l}\text { Mellergård } \\
\text { et al. (2012) }\end{array}$ & $\begin{array}{l}\text { - Microdialysis } \\
\text { catheters } \\
\text { CMA } 71 \\
\text { - Perfused using } \\
\text { microdialysis } \\
\text { pump CMA } 106 \\
\text { - Microdialysis } \\
\text { analyzer } \\
\text { CMA } 600\end{array}$ & 69 & $\begin{array}{l}\text { - Severe TBI } \\
\text { - Glasgow Outcome Scale (GOS) } \\
\text { scores: } 21 \text { patients with a score } \\
\text { of } 1,1 \text { with a score of } 2,11 \text { with } \\
\text { a score of } 3,8 \text { with a score of } 4 \text {, } \\
16 \text { with a score of } 5 \text { and } 12 \text { with } \\
\text { an unknown score }\end{array}$ & $\begin{array}{l}\text { - Sex: } 48 \text { males } \\
21 \text { females } \\
\text { - Mean age: } 45.9 \text { years }\end{array}$ & $\begin{array}{l}\text { - Lactate in patients }<25 \text { years was } \\
5.0 \pm 0.06 \mathrm{mmol} / \mathrm{L}, 25-45 \text { years } \\
\text { was } 5.0 \pm 0.06 \mathrm{mmol} / \mathrm{L} \text {, } \\
45-65 \text { years was } 6.0 \pm 0.08 \mathrm{mmol} / \\
\mathrm{L} \text { and }>65 \text { years was } \\
6.3 \pm 0.13 \mathrm{mmol} / \mathrm{L} \\
\text { - Older patients had increased levels } \\
\text { and suffered poor outcomes } \\
\text { - Pyruvate in patients }<25 \text { years was } \\
221 \pm 2.55 \mathrm{mmol} / \mathrm{L}, 25-45 \text { years } \\
\text { was } 216 \pm 2.43 \mathrm{mmol} / \mathrm{L}, \\
45-65 \text { years was } 256 \pm 2.73 \text { mmol} / \\
L \text { and }>65 \text { years was } \\
227 \pm 4.20 \mathrm{mmol} / \mathrm{L} \\
\text { - Older patients had increased levels } \\
\text { and suffered poor outcomes }\end{array}$ \\
\hline $\begin{array}{l}\text { Kurtz et al. } \\
\text { (2013) }\end{array}$ & $\begin{array}{l}\text { - Microdialysis } \\
\text { catheter CMA } 70 \\
\text { - Perfused using } \\
\text { microdialysis } \\
\text { pump CMA } 106 \\
\text { - Microdialysis } \\
\text { analyzer } \\
\text { CMA } 600\end{array}$ & 46 & $\begin{array}{l}\text { - Moderate to severe brain injury } \\
\text { - Median age was } 55 \text { IQR } \\
\text { 42-64 years with } 27 \text { females } \\
\text { and } 19 \text { males } \\
\text { - Median GCS and IQR was 7, 5-9 }\end{array}$ & $\begin{array}{l}\text { - Sex: } 27 \text { females } \\
19 \text { males } \\
\text { - Median age: 55 IQR 42-64 years }\end{array}$ & $\begin{array}{l}\text { - Median lactate was } 3.9 \text { IQR } \\
\text { 2.9-4.8 mmol/L } \\
\text { - Levels were high and linked to } \\
\text { cerebral metabolic distress and } \\
\text { increased mortality, } p<0.001 \\
\text { - Median pyruvate was } 123 \text { IQR } \\
\text { 92-160 } \mu \mathrm{mol} / \mathrm{L} \\
\text { - Levels were low and linked to } \\
\text { cerebral metabolic distress and } \\
\text { increased mortality, } p<0.001\end{array}$ \\
\hline
\end{tabular}

$\%$ = percentage, CMA, cerebral microdialysis analyzer; CMD, cerebral microdialysis; GCS, glasgow coma scale; GOS, glasgow outcome scale; $I Q R$, interquartile range, mmol/L= millimole per liter, $\mathrm{p}=\mathrm{p}$-value, $\mathrm{TB}$, traumatic brain injury, $r=$ correlation coefficient, $\mu \mathrm{mol} / \mathrm{L}=$ micromole per liter.

$(p=0.002)$ (Sorrentino et al., 2012). Further to this, the early study by Czosnyka et al. showed that females $<50$ years suffered worse cerebrovascular reactivity compared to males, as evidenced by mean PRx for females of $0.11 \pm 0.047$ a. u. vs. $0.044 \pm 0.031$ a. u. for males $(p<0.05)$ (Czosnyka et al., 2008). Patients $>50$ years old in this study did not show comparable differences between males and females (Czosnyka et al., 2008). Of note, we have only commented on those studies on PRx. There exists an extensive and ever-growing literature in moderate/severe TBI on other cerebrovascular reactivity indices, derived from various invasive/ non-invasive cerebral monitoring devices (Zeiler et al., 2017d). Figures 1, 2 provide patient examples of high-resolution physiology, documenting differences in ICP, CPP, PRx and $\mathrm{rSO}_{2}$ for a young and elderly patient, respectively.

\section{Compensatory Reserve}

Cerebral compensatory reserve monitoring through continuously updating bedside metrics has recently been described in the TBI literature (Kim et al., 2009; Calviello et al., 2018; Zeiler et al., 2018c; Zeiler et al., 2019b). Such measures help with approximating how "tight" or "relaxed" the brain may be post-TBI. RAP ( $\mathrm{R}$ - correlation, A - pulse amplitude of ICP, $\mathrm{P}$ - intracranial pressure) is an index which is derived from the relationship between slow-wave vasogenic fluctuations in ICP and pulse amplitude of ICP (Kim et al., 2009). This gives a constant bedside evaluation of cerebral compensatory reserve where impairment is linked to increased mortality (Calviello et al., 2018; Zeiler et al., 2018c). Further work into RAP is needed in order to employ its use in TBI patients, though preliminary data supports an association between abnormal RAP measures and worse outcomes. As such, there exists a limited literature body documenting the association between RAP and age/biological sex in moderate/severe TBI, with those in existence demonstrating that older patients tended to have undesirable outcomes (Czosnyka et al., 1996b; Zeiler et al., 2018c; Zeiler et al., 2019b). The first study by Zeiler et al. had no difference in mean RAP values between males and females $(p>0.05)$ and no relationship with age $(p>0.05)$ (Zeiler et al., $2018 c$ ). The follow-up study by Zeiler et al. demonstrated that increased age and compensatory-reserve-weighted intracranial pressure (wICP) was linked to poor outcomes (Zeiler et al., 2019b). Males were predominant in these studies and no major association was made between the sexes. Table 3 provides a summary of the available RAP literature, documenting any link to age and sex.

\section{CEREBRAL MICRODIALYSIS - STANDARD ANALYTES}

CMD is an invasive method of analyzing extracellular fluid for both metabolites and protein biomarkers (Timofeev et al., 
2011; Hutchinson et al., 2015; Zeiler et al., 2017b). Classically, CMD is utilized to provide bedside information regarding cerebral metabolites, and typically includes the hourly analysis of: glucose, glycerol, glutamate, lactate and pyruvate. CMD has also been applied to explore for novel biomarkers of injury and physiologic dysfunction (Zeiler et al., 2017c; Helmy et al., 2011a; Guilfoyle et al., 2015). The standard metabolic data obtained from CMD, can be key in guiding clinical therapy and avoiding secondary brain injury and poor outcomes (Timofeev et al., 2011). Though it must be acknowledged, to date CMD use has been limited to a few specialized centers globally, with limited published literature on the topic (Zeiler et al., 2017b). As with all of the described cerebral monitoring devices in moderate/severe TBI, the available literature documenting links between CMD analytes and age/biological sex are limited. Table 4 provides a list of the main available studies documenting such associations with standard CMD analytes. Studies examined generally show that older patients tended to have undesirable outcomes along with those who had low glucose, low pyruvate, high glycerol, high glutamate and high lactate levels, though many of the relationships failed to reach statistical significance (Clausen et al., 2005; Chamoun et al., 2010; Mellergård et al., 2012; Stein et al., 2012; Kurtz et al., 2013). Stein et al. showed that older patients compared to younger patients (median age 50.5 (IQR: 38.3-62.0) vs. 32.5 (IQR: $26.3-45.0$ years), respectively; $p=0.008$ ) with lower glucose $(p=0.061)$, lower glycerol $(p=0.998)$, higher glutamate $(p=0.027)$, higher lactate $(p=0.132)$ and lower pyruvate $(p=$ 0.978 ) suffered poor outcomes (Stein et al., 2012). Further to this, a study by Mellergard et al. demonstrated that older patients tended to have higher glycerol, higher glutamate, higher lactate and pyruvate (Mellergård et al., 2012). Such patients tended to suffer poor outcomes (Clausen et al., 2005; Chamoun et al., 2010; Mellergård et al., 2012; Stein et al., 2012). Males were predominant in most studies but no comparisons were made between the biological sex categories and CMD analytes.

\section{LIMITATIONS}

As can be seen by the overviewed literature body, the available data is heterogeneous, with significant disparities both within and between monitoring modalities. It must be acknowledged that the goal of our review is not to be exhaustively comprehensive in outlining every article in existence with respect to age/sex and the specific monitoring. However, we did highlight the most representative/pertinent articles, with some of the largest moderate/severe TBI populations, for each high-frequency continuous MMM metric. Our findings do highlight the need for dedicated research on the biological influence of aging and sex on MMM measures, as most of the outlined studies focus on basic associations between chronological age, or binary sex designations, with gross summary metrics for each monitoring variable gained from calculated mean/median over large epochs of monitoring, often over the entire ICU stay. All studies focused mainly on grand averaged data over large epochs of acute phase physiology. Such coarse summary metrics make it near impossible to determine if sub-classes of physiologic profiles exist based on age and sex. This is an important consideration for the design of future studies on the topic.

\section{CONSIDERATIONS AND FUTURE DIRECTIONS}

Our review has highlighted an important gap in knowledge pertaining to MMM in TBI. The existing literature body on the impacts of aging and sex on the cerebral vasculature outside of TBI does provide us some clues as to critical considerations, when planning for future studies on the topic. As much of the MMM based metrics are grounded in cerebrovascular physiologic responses, exploring such non-TBI literature bodies may provide important insights. We will briefly touch on some of these biological factors, but refer the reader to the referenced literature body for more nuanced detail, if desired. Finally, the last subsection outlines some important considerations for future studies moving forward.

\section{Advanced Age as a Biological Consideration}

Advanced age is known to be associated with impaired cerebrovascular response through cerebrovascular reactivity testing in healthy populations during $\mathrm{pCO}_{2}$ challenges in concert with advanced functional neuroimaging (McKetton et al., 2018; Miller et al., 2019; Taneja et al., 2020), and TCD assessments of MCA CBFV (Mariappan et al., 2015; AguilarNavarro et al., 2019; Klein et al., 2020; Tomoto et al., 2020). This has been confirmed in both populations of awake and anesthetized patients. We have also seen that advanced age is associated with worse cerebrovascular reactivity in moderate/ severe TBI patients in our above review of MMM (Czosnyka et al., 2005; Zeiler et al., 2019a; Zeiler et al., 2019c).

There are a variety of pathological changes that could be associated with impaired cerebral vascular performance during the aging process (Camici et al., 2015). First, accumulation of amyloid protein precursor and beta amyloid in the wall of cerebral vessels has long been known to occur with advancing age, as seen in both human literature and experimental models (Grinberg et al., 2012; Weller et al., 2015; Qi and Ma, 2017). Such accumulation has been linked to reduced endothelial nitric oxide (NO) activity secondary to shuttling to the formation of peroxynitrite, and an increase in reactive oxygen species (ROS) (Hamel et al., 2008; Carvalho and Moreira, 2018). This leads to impaired resting tone, as well as attenuated vasodilatory responses of the cerebral vessels. In addition, the general response of the cerebral vasculature to free radicals and ROS becomes impaired. The angiotensin II (AGT) pathway is known to be involved in ROS vascular responses. With advanced aging, it appears that there is an uninhibited angiotensin II mediated generation of ROS, further potentiating the impacts on the NO 
vasodilatory pathways (Hamel et al., 2008; Camici et al., 2015; Carvalho and Moreira, 2018; Wang et al., 2019).

Aside from NO/ROS mediated changes seen with aging, chronic inflammation has also emerged as a potentially important pathological driver of cerebrovascular dysfunction (Gu et al., 2019; Low et al., 2019; Mészáros et al., 2020).Advanced age has demonstrated increased expression of various systemic pro-inflammatory cytokines, such as interleukin (IL)-1B and IL-6, in both experimental and human literature (Gu et al., 2019). This response is believed to be a maladaptive autoimmune action to cellular breakdown products found during the normal aging process. Furthermore, recent literature also suggests some of the chronic cerebral vascular changes seen with aging, such as amyloid deposition, lead to increased leukocyte adhesion, further potentiating the immune response (Gu et al., 2019; Low et al., 2019; Mészáros et al., 2020). This chronic immune response may be linked to ongoing dysfunction in the central nervous system, and degeneration. Increased circulating IL-6 levels have even been associated with magnetic resonance imaging (MRI) defined white matter ischemic volumes in elderly populations (Gu et al., 2019; Low et al., 2019). The exact mechanism of cerebrovascular dysfunction related to chronic neuroinflammation remains unclear at this time. However, of interest, the acute TBI literature has also found strong associations between serum and cerebrospinal fluid (CSF) pro-inflammatory cytokines, such as IL-6, with poor long-term outcome (Thelin et al., 2017a; Zeiler et al., 2017c; Thelin et al., 2018). Furthermore, the impact of the immune response post-TBI has also been supported by the association between various single nucleotide polymorphisms (SNP) in genes regulating proinflammatory cytokines, and patient outcomes (Zeiler et al., 2019e; Zeiler et al., 2019f). Genetic variation in immune response has also been highlighted as an important consideration in the genetics of biological aging, where SNP's in IL-6 has been underlined as an important future area to consider in aging research (Cardoso et al., 2018).

Finally, neural modulation and repair mechanisms are also impaired as a result of aging. Decreased expression of brain derived neurotropic factor (BDNF) has been recently associated with advancing age. SNP's in BDNF have also received note as potential areas of importance for future research in aging (Cardoso et al., 2018). Of note, BDNF SNP's have also been linked to long-term outcomes in adult TBI literature (Zeiler et al., 2019e; Zeiler et al., 2019f). It may be that specific BDNF SNP's potentiate impaired BDNF expression associated with aging, which leads to reduction in downstream regenerative mechanisms post-injury. Such impaired recovery mechanisms in the central nervous system may lead to increase in the pro-inflammatory process described previously, leading to worse cerebral vascular function.

\section{Sex as a Biological Consideration}

As an additional layer of complexity, biological sex has some potentially major roles to play in cerebral vascular responses both in healthy and disease states. It impacts cerebrovascular responses both independent of, but also potentially mixed effects with, advancing age. With respect to moderate/severe TBI, the incidence of such injury overwhelmingly favors males. The majority of studies to date on TBI have had male predominance in their cohorts, limiting proper assessment of the impact of sex on secondary injury patterns and outcome (Maas et al., 2017; Steyerberg et al., 2019). This is also the case with all of the above-mentioned studies on MMM and their association with biological sex. However, biologically, sex differences leave important considerations regarding disparities in treatment responses, secondary injury severity, and outcomes (Mikolić et al., 2021).

With regards to progesterone in moderate/severe TBI, as mentioned in the introduction, substantial prior work has been conducted. Pre-clinical models of TBI have provided evidence that progesterone carries a neuroprotective effect, with exogenous supplementation in animals leading to reduced neural loss, improved neurophysiologic and functional outcomes (Clevenger et al., 2018; Khaksari et al., 2018). In humans, sex-related disparities in outcome after moderate/ severe TBI have been well documented, despite the overwhelming majority of patients being male (Maas et al., 2017; Steyerberg et al., 2019; Mikolić et al., 2021). Supplementation with progesterone has been explored in such TBI cohorts in numerous randomized control trials evaluating the impact on long-term global outcomes, including the Progesterone for Traumatic Brain Injury, Experimental Clinical Treatment (ProTECT) (Wright et al., 2007402) and Efficacy and Safety Study of Intravenous Progesterone in Patients With Severe Traumatic Brain Injury (SyNAPSe) Trials (Skolnick et al., 2014). However, despite early evidence suggesting a potential impact on mortality and functional outcome (Pan et al., 2019), all trials have failed to demonstrate long-term impacts on mortality and morbidity (Lu et al., 2016; Ma et al., 2016; Schumacher et al., 2016; Pan et al., 2019). Though, functional outcomes assessments in trials were limited to course outcomes metrics, standard in moderate/severe TBI, such as the Glasgow Outcome Scale (Lu et al., 2016; Ma et al., 2016; Pan et al., 2019). Similarly, progesterone supplementation has also failed to lead to reproducible measurable differences in biomarkers of neural injury in such populations (Korley et al., 2021). To date no assessments of sex steroid supplementation and its impact on high-frequency cerebral physiology in adult moderate/severe TBI have been conducted.

Aside from progesterone, circulating estrogen levels have a well-documented impact on cerebral vasculature (Krause et al., 1985). Estrogen is known to promote prostaglandin I2 (PGI2) release, an important vasodilator (Krause et al., 1985; Deer and Stallone, 2014). Similarly, in males, or instances of low estrogen production, thromboxane A2 (TXA2) predominates, leading to cerebral vasoconstriction and impaired vasodilatory responses of the cerebral vessels (Deer and Stallone, 2014). Furthermore, in young female mice with higher circulating estrogen levels, there appears to be an attenuated angiotensin II/ROS response, with reduced vasoconstriction responses seen in female models to ROS exposures (De Silva et al., 2009). Finally, experimental literature points to high endothelial nitric oxide synthase (eNOS) vasodilation in female versus male rats, under exercise conditions (Arrick et al., 2016). 
Aside from the endothelial and myogenic impacts of estrogen on the cerebral vasculature, there is a known anti-inflammatory effect. Data suggests that higher circulating estrogen levels are linked to decrease in leukocyte adhesion to the cerebral vasculature (Krause et al., 1985). Furthermore, estrogen has been shown to decrease inducible nitric oxide synthase (iNOS) in response to $\mathrm{IL}-1 \mathrm{~B}$, which is linked to upregulation of cyclooxygenase-2 (COX-2) and prostaglandin E2 (PGE2). As COX-2 and PGE2 are known cerebral vasoconstrictors, circulating estrogen levels subsequently attenuate their responses in the setting of injury (Krause et al., 1985). These anti-inflammatory properties of estrogen have triggered neuroprotective studies in both experimental and human settings (Brotfain et al., 2016; Späni et al., 2018; MartinJiménez et al., 2019; Yilmaz et al., 2019). However, their impact on global outcome post-TBI in humans is still uncertain.

Finally, aside from estrogenic endothelial/myogenic and antiinflammatory effects, there have been documented differences in potassium channel expression in males vs. females, with a direct link to estrogen levels (Reed et al., 2020). In rats, large potassium channel beta-1 subunit (BK-B1) displays decreased expression in both males and female rats with removed ovaries. This BK-B1 reduction leads to increased MCA reactivity, as the large potassium channels are known to regulate cerebrovascular myogenic activity. This has yet to be substantiated in humans, but carries potential to explain discrepancies in cerebrovascular physiology seen in health and disease.

\section{Potential Mixed Biological Effects of Aging and Sex}

Accounting of the biological impacts of aging and sex highlighted above, it's clear that there is a potential for interaction on cerebrovascular function in the setting of TBI. This is particularly the case for aging females (Krause et al., 1985). During youth, females do benefit from the protective effects of higher circulating estrogen on cerebral vasculature. However, during menopause or post oophorectomy the risk profile may change. Menopause in particular, occurring with advancing age may now dramatically increase the risk of abnormal vascular responses in the setting of TBI. Such changes may be reflected in the emerging literature suggesting worse long-term outcomes for females suffering from TBI. It must be noted that in reviewing the above-outlined literature on MMM and its association between age and biological sex, there were no studies identified which adjusted for both age and sex in a multi-variable model. This is despite having age and sex information available in their core data sets. As such, it is clear that such future works in this area will need to evaluate such age/sex interactions in a more comprehensive manner.

\section{Future Directions}

As outlined in the review on MMM provided and overview of the cerebrovascular biological considerations of aging and sex, there are some key areas for future investigation. First, the initial future works on MMM and its links with age and sex, require the use of high-resolution measures (Smieleweski and Czosnyka, 20002021). Relying on grand mean summary metrics for MMM physiology is insufficient, as signal variance is essentially eliminated, and the ability to discern sub-classes based on age and sex near impossible. As such, future works in the area require the use of time-series methodologies (Thelin et al., 2019; Zeiler et al., 2020e; Zeiler et al., 2020f), including autoregressive integrative moving average (ARIMA) and vector autoregressive integrative moving average (VARIMA) techniques. These should be applied based on large populations of TBI patients with highfrequency physiology, using sub-groups of age and sex. Further, sub-class evaluation can take place using semi-supervised or unsupervised machine learning techniques, and latent class analytics. Furthermore, more complex multi-variable models adjusting for age and sex are needed, as such literature is lacking. Such analyses may facilitate answering some of the preliminary questions regarding age/sex interactions, which currently remain unanswered in moderate/severe TBI. This work is the focus of various multi-center groups focused on high-frequency physiology data processing in both Europe (Howells et al., 2012; Maas et al., 2015; Güiza et al., 2017; Bennis et al., 2020) and Canada (Zeiler et al., 2018d; Bernard et al., 2020), and requires multi-disciplinary integrated teams of clinicians, engineers, physiologists and data scientists.

Aside from the initial more detailed analytic pathways for MMM physiology, the second phase of such inquiry necessitates integration of the physiome data with proteomic and genomic information. In general, genome wide association data (Zeiler et al., 2019e; Zeiler et al., 2019f), combined with proteomic information (Timofeev et al., 2011; Maas et al., 2015; Thelin et al., 2017b), may shed light on particular pathways driving cerebral physiologic dysfunction in TBI. However, with respect to aging and sex, integrating blood/serum/CSF/microdialysate sampling during the acute phase of TBI care, with highresolution MMM data is key. First, blood can be utilized for genome wide association studies (GWAS), identifying various SNP's of interest, including those related to pro-inflammatory cytokines, neural repair and angiotensin pathways that are of interest in advanced age (Cardoso et al., 2018; Zeiler et al., 2019f). Second, serum/CSF/microdialysate can be exploited to quantify circulating levels of cytokines (Helmy et al., 2011a; Helmy et al., 2011b; Zeiler et al., 2017c; Thelin et al., 2018), such as IL-6, nitric oxide synthase activity (through nitrate/nitrite levels), prostaglandin levels, free radical analysis, and assessment of sex hormone concentrations. Finally, blood can also be exploited to provide proper quantification of biological age, using current epigenetic techniques (Ishikawa et al., 2016; Bisset and Howlett, 2019; Zarzour et al., 2019). It is well known the chronological age is a poor marker of biological age and function. Epigenetic techniques evaluating widespread genome methylation status, histone modifications, or telomere length of circulating white cells, can be used to quantify biological age. Such epigenetic information may allow us to more accurately determine biological age and its link to MMM based physiologic dysfunction in TBI. However, such work is easy to describe, but much more complicated to execute. As with the advanced signal analytics, such work requires large multi-center data sets for 
reasons of statistical power and multi-disciplinary expertise. Some preliminary work in this area is being done using the CENTER-TBI high-resolution data set (Maas et al., 2015), but will only set the stage for future larger multi-center works in the area of advanced omics research in TBI.

\section{CONCLUSION}

The current literature body on the association between age and sex with high-frequency continuous MMM based cerebral physiological measures in moderate/severe TBI is lacking. Most studies use coarse summary metrics, documenting association between physiology and chronological age and/or binary sex designations. Few studies to date account for biological processes of aging and sex, and their impact on MMM physiology. Future work on the impact of aging and sex on MMM physiology in TBI will require advanced signal analytic techniques, with integrated proteomic and genomic data, while accounting for biological age using epigenetics.

\section{AUTHOR CONTRIBUTIONS}

$\mathrm{CB}$ and $\mathrm{AG}$ were responsible for design, manuscript composition and editing. LF was responsible for figure generation, manuscript

\section{REFERENCES}

Aaslid, R., Markwalder, T. M., and Nornes, H. (1982). Noninvasive Transcranial Doppler Ultrasound Recording of Flow Velocity in Basal Cerebral Arteries. J. Neurosurg. 57, 769-774. doi:10.3171/ jns.1982.57.6.0769

Adams, H., Donnelly, J., Czosnyka, M., Kolias, A. G., Helmy, A., Menon, D. K., et al. (2017). Temporal Profile of Intracranial Pressure and Cerebrovascular Reactivity in Severe Traumatic Brain Injury and Association with Fatal Outcome: An Observational Study. Plos Med. 14, e1002353. doi:10.1371/ journal.pmed.1002353

Adatia, K., Geocadin, R. G., Healy, R., Ziai, W., Ponce-Mejia, L., Anderson-White, M., et al. (2018). Effect of Body Temperature on Cerebral Autoregulation in Acutely Comatose Neurocritically Ill Patients. Crit. Care Med. 46, e733-e741. doi:10.1097/CCM.0000000000003181

Adatia, K., Geocadin, R. G., Healy, R., Ziai, W., Ponce-Mejia, L., Anderson-White, M., et al. (2020). Lateral Brain Displacement and Cerebral Autoregulation in Acutely Comatose Patients. Crit. Care Med. 48, 1018-1025. doi:10.1097/ CCM.0000000000004365

Aguilar-Navarro, S. G., Mimenza-Alvarado, A. J., Corona-Sevilla, I., JiménezCastillo, G. A., Juárez-Cedillo, T., Ávila-Funes, J. A., et al. (2019). Cerebral Vascular Reactivity in Frail Older Adults with Vascular Cognitive Impairment. Brain Sci. 9, 1. doi:10.3390/brainsci9090214

Åkerlund, C. A., Donnelly, J., Zeiler, F. A., Helbok, R., Holst, A., Cabeleira, M., et al. (2020). Impact of Duration and Magnitude of Raised Intracranial Pressure on Outcome after Severe Traumatic Brain Injury: A CENTER-TBI High-Resolution Group Study. PLoS One 15, e0243427. doi:10.1371/journal.pone.0243427

Alwatban, M. R., Aaron, S. E., Kaufman, C. S., Barnes, J. N., Brassard, P., Ward, J. L., et al. (2021). Effects of Age and Sex on Middle Cerebral Artery Blood Velocity and Flow Pulsatility index across the Adult Lifespan. J. Appl. Physiol. 130, 1675-1683. doi:10.1152/japplphysiol.00926.2020

Arrick, D. M., Li, C., and Mayhan, W. G. (2016). Sex-related Differences in Reactivity of Cerebral Arterioles during Moderate Exercise Training. Microcirculation 23, 549-557. doi:10.1111/micc.12306 composition and editing. AS was responsible for manuscript composition and editing. FZ was responsible for concept, design, supervision, manuscript composition and editing.

\section{FUNDING}

This work was directly supported through the University of Manitoba Centre on Aging Fellowship. In addition, FZ receives research support from the Manitoba Public Insurance (MPI) Neuroscience/TBI Research Endowment, the United States National Institutes of Health (NIH) through the National Institute of Neurological Disorders and Stroke (NINDS) (Grant \#: R03NS114335-01), the Canadian Institutes of Health Research (CIHR) (Grant \#: 432,061), the Canada Foundation for Innovation (CFI) (Project \#: 38,583), Research Manitoba (Grant \#: 3906), the University of Manitoba VPRI Research Investment Fund (RIF), the University of Manitoba Centre on Aging, and the University of Manitoba Rudy Falk Clinician-Scientist Professorship. CB is supported through the Centre on Aging Fellowship at the University of Manitoba. LF is supported through the University of Manitoba - Department of Surgery GFT Research Grant, and the University of Manitoba Office of Research Services (ORS) - University Research Grant Program (URGP). AG is supported through the University of Manitoba Clinician Investigator Program.

Bakker, S. L. M., Leeuw, F.-E. de., Heijer, T. den., Koudstaal, P. J., Hofman, A., and Breteler, M. M. B. (2004). Cerebral Haemodynamics in the Elderly: The Rotterdam Study. NED 23, 178-184.

Bennis, F. C., Teeuwen, B., Zeiler, F. A., Elting, J. W., van der Naalt, J., Bonizzi, P., et al. (2020). Improving Prediction of Favourable Outcome after 6 Months in Patients with Severe Traumatic Brain Injury Using Physiological Cerebral Parameters in a Multivariable Logistic Regression Model. Neurocrit. Care 33 (2), 542-551. doi:10.1007/s12028-020-00930-6

Beqiri, E., Smielewski, P., Robba, C., Czosnyka, M., Cabeleira, M. T., Tas, J., et al. (2019). Feasibility of Individualised Severe Traumatic Brain Injury Management Using an Automated Assessment of Optimal Cerebral Perfusion Pressure: the COGiTATE Phase II Study Protocol. BMJ Open 9, e030727. doi:10.1136/bmjopen-2019-030727

Bernard, F., Gallagher, C., Griesdale, D., Kramer, A., Sekhon, M., and Zeiler, F. A. (2020). The Canadian High-Resolution Traumatic Brain Injury (CAHR-TBI) Research Collaborative. Can. J. Neurol. Sci. 47, 551-556. doi:10.1017/cjn.2020.54

Bisset, E. S., and Howlett, S. E. (2019). The Biology of Frailty in Humans and Animals: Understanding Frailty and Promoting Translation. Aging Med. (Milton) 2, 27-34. doi:10.1002/agm2.12058

Bouzat, P., Francony, G., Declety, P., Genty, C., Kaddour, A., Bessou, P., et al. (2011). Transcranial Doppler to Screen on Admission Patients with Mild to Moderate Traumatic Brain Injury. Neurosurgery 68, 1603-1610. doi:10.1227/ NEU.0b013e31820cd43e

Brotfain, E., Gruenbaum, S. E., Boyko, M., Kutz, R., Zlotnik, A., and Klein, M. (2016). Neuroprotection by Estrogen and Progesterone in Traumatic Brain Injury and Spinal Cord Injury. Curr. Neuropharmacol. 14, 641-653. doi:10.2174/1570159x14666160309123554

Budohoski, K. P., Reinhard, M., Aries, M. J., Czosnyka, Z., Smielewski, P., Pickard, J. D., et al. (2012). Monitoring Cerebral Autoregulation after Head Injury. Which Component of Transcranial Doppler Flow Velocity Is Optimal? Neurocrit. Care 17, 211-218. doi:10.1007/s12028-011-9572-1

Burkhart, C. S., Rossi, A., Dell-Kuster, S., Gamberini, M., Möckli, A., Siegemund, M., et al. (2011). Effect of Age on Intraoperative Cerebrovascular Autoregulation and Near-Infrared Spectroscopy-Derived Cerebral Oxygenation. Br. J. Anaesth. 107, 742-748. doi:10.1093/bja/aer252 
Calviello, L., Donnelly, J., Cardim, D., Robba, C., Zeiler, F. A., Smielewski, P., et al. (2018). Compensatory-Reserve-Weighted Intracranial Pressure and its Association with Outcome after Traumatic Brain Injury. Neurocrit. Care 28, 212-220. doi:10.1007/s12028-017-0475-7

Camici, G. G., Savarese, G., Akhmedov, A., and Lüscher, T. F. (2015). Molecular Mechanism of Endothelial and Vascular Aging: Implications for Cardiovascular Disease. Eur. Heart J. 36, 3392-3403. doi:10.1093/eurheartj/ehv587

Cardim, D., Czosnyka, M., Chandrapatham, K., Badenes, R., Bertuccio, A., Corradi, F., et al. (2020). Arterial and Venous Cerebral Blood Flow Velocities and Their Correlation in Healthy Volunteers and Traumatic Brain Injury Patients. J. Neurosurg. Anesthesiol. 1, 1. doi:10.1097/ANA.0000000000000704

Cardoso, A. L., Fernandes, A., Aguilar-Pimentel, J. A., de Angelis, M. H., Guedes, J. R., Brito, M. A., et al. (2018). Towards Frailty Biomarkers: Candidates from Genes and Pathways Regulated in Aging and Age-Related Diseases. Ageing Res. Rev. 47, 214-277. doi:10.1016/j.arr.2018.07.004

Carney, N., Totten, A. M., O’Reilly, C., Ullman, J. S., Hawryluk, G. W., Bell, M. J., et al. (2017). Guidelines for the Management of Severe Traumatic Brain Injury, Fourth Edition. Neurosurgery 80, 6-15. doi:10.1227/NEU.0000000000001432

Carvalho, C., and Moreira, P. I. (2018). Oxidative Stress: A Major Player in Cerebrovascular Alterations Associated to Neurodegenerative Events. Front. Physiol. 9, 806. doi:10.3389/fphys.2018.00806

Chamoun, R., Suki, D., Gopinath, S. P., Goodman, J. C., and Robertson, C. (2010). Role of Extracellular Glutamate Measured by Cerebral Microdialysis in Severe Traumatic Brain Injury. J. Neurosurg. 113, 564-570. doi:10.3171/2009.12.JNS09689

Chesnut, R., Aguilera, S., Buki, A., Bulger, E., Citerio, G., Cooper, D. J., et al. (2020). A Management Algorithm for Adult Patients with Both Brain Oxygen and Intracranial Pressure Monitoring: the Seattle International Severe Traumatic Brain Injury Consensus Conference (SIBICC). Intensive Care Med. 46, 919-929. doi:10.1007/s00134-019-05900-x

Clausen, T., Khaldi, A., Zauner, A., Reinert, M., Doppenberg, E., Menzel, M., et al. (2005). Cerebral Acid-Base Homeostasis after Severe Traumatic Brain Injury. J. Neurosurg. 103, 597-607. doi:10.3171/jns.2005.103.4.0597

Clevenger, A. C., Kim, H., Salcedo, E., Yonchek, J. C., Rodgers, K. M., Orfila, J. E., et al. (2018). Endogenous Sex Steroids Dampen Neuroinflammation and Improve Outcome of Traumatic Brain Injury in Mice. J. Mol. Neurosci. 64, 410-420. doi:10.1007/s12031-018-1038-x

Czosnyka, M., Balestreri, M., Steiner, L., Smielewski, P., Hutchinson, P. J., Matta, B., et al. (2005). Age, Intracranial Pressure, Autoregulation, and Outcome after Brain Trauma. J. Neurosurg. 102, 450-454. doi:10.3171/jns.2005.102.3.0450

Czosnyka, M., Guazzo, E., Whitehouse, M., Smielewski, P., Czosnyka, Z., Kirkpatrick, P., et al. (1996b). Significance of Intracranial Pressure Waveform Analysis after Head Injury. Acta Neurochir. (Wien) 138, 531-532. doi:10.1007/BF01411173

Czosnyka, M., Radolovich, D., Balestreri, M., Lavinio, A., Hutchinson, P., Timofeev, I., et al. (2008). Gender-related Differences in Intracranial Hypertension and Outcome after Traumatic Brain Injury. Acta Neurochir. Suppl. 102, 25-28. doi:10.1007/978-3-211-85578-2_5

Czosnyka, M., Richards, H. K., Whitehouse, H. E., and Pickard, J. D. (1996a). Relationship between Transcranial Doppler-Determined Pulsatility index and Cerebrovascular Resistance: an Experimental Study. J. Neurosurg. 84, 79-84. doi:10.3171/jns.1996.84.1.0079

Czosnyka, M., Smielewski, P., Kirkpatrick, P., Laing, R. J., Menon, D., and Pickard, J. D. (1997). Continuous Assessment of the Cerebral Vasomotor Reactivity in Head Injury. Neurosurgery 41, 11-19. doi:10.1097/00006123-199707000-00005

Czosnyka, M., Whitehouse, H., Smielewski, P., Kirkpatrick, P., Guazzo, E. P., and Pickard, J. D. (1994). Computer Supported Multimodal Bed-Side Monitoring for Neuro Intensive Care. Int. J. Clin. Monit. Comput. 11, 223-232. doi:10.1007/ BF01139874

De Silva, T. M., Broughton, B. R., Drummond, G. R., Sobey, C. G., and Miller, A. A. (2009). Gender Influences Cerebral Vascular Responses to Angiotensin II through Nox2-Derived Reactive Oxygen Species. Stroke 40, 1091-1097. doi:10.1161/STROKEAHA.108.531707

Deer, R. R., and Stallone, J. N. (2014). Effects of Age and Sex on Cerebrovascular Function in the Rat Middle Cerebral Artery. Biol. Sex. Differ. 5, 12. doi:10.1186/ s13293-014-0012-8

Dias, C., Silva, M. J., Pereira, E., Monteiro, E., Maia, I., Barbosa, S., et al. (2015). Optimal Cerebral Perfusion Pressure Management at Bedside: A Single-Center Pilot Study. Neurocrit. Care 23, 92-102. doi:10.1007/s12028-014-0103-8
Dickman, C. A., Carter, L. P., Baldwin, H. Z., Harrington, T., and Tallman, D. (1991). Continuous Regional Cerebral Blood Flow Monitoring in Acute Craniocerebral Trauma. Neurosurgery 28, 467-472. doi:10.1097/00006123199103000-00026

Donnelly, J., Czosnyka, M., Adams, H., Cardim, D., Kolias, A. G., Zeiler, F. A., et al. (2019). Twenty-Five Years of Intracranial Pressure Monitoring after Severe Traumatic Brain Injury: A Retrospective, Single-Center Analysis. Neurosurgery 85, E75-E82. doi:10.1093/neuros/nyy468

Donnelly, J., Güiza, F., Depreitere, B., Meyfroidt, G., Czosnyka, M., and Smielewski, P. (2020). Visualising the Pressure-Time burden of Elevated Intracranial Pressure after Severe Traumatic Brain Injury: a Retrospective Confirmatory Study. Br. J. Anaesth. 126 (1), e15-e17. doi:10.1016/j.bja.2020.09.018

Froese, L., Batson, C., Gomez, A., Dian, J., and Zeiler, F. A. (2021). The Limited Impact of Current Therapeutic Interventions on Cerebrovascular Reactivity in Traumatic Brain Injury: A Narrative Overview. Neurocrit. Care 34, 325-335. doi:10.1007/s12028-020-01003-4

Gao, L., Smielewski, P., Czosnyka, M., and Ercole, A. (2017). Early Asymmetric Cardio-Cerebral Causality and Outcome after Severe Traumatic Brain Injury. J. Neurotrauma 34, 2743-2752. doi:10.1089/neu.2016.4787

Grinberg, L. T., Korczyn, A. D., and Heinsen, H. (2012). Cerebral Amyloid Angiopathy Impact on Endothelium. Exp. Gerontol. 47, 838-842. doi:10.1016/j.exger.2012.08.005

Gu, Y., Gutierrez, J., Meier, I. B., Guzman, V. A., Manly, J. J., Schupf, N., et al. (2019). Circulating Inflammatory Biomarkers Are Related to Cerebrovascular Disease in Older Adults. Neurol. Neuroimmunol. Neuroinflamm. 6, e521. doi:10.1212/NXI.0000000000000521

Guilfoyle, M. R., Carpenter, K. L., Helmy, A., Pickard, J. D., Menon, D. K., and Hutchinson, P. J. (2015). Matrix Metalloproteinase Expression in Contusional Traumatic Brain Injury: A Paired Microdialysis Study. J. Neurotrauma 32, 1553-1559. doi:10.1089/neu.2014.3764

Güiza, F., Depreitere, B., Piper, I., Citerio, G., Chambers, I., Jones, P. A., et al. (2015). Visualizing the Pressure and Time burden of Intracranial Hypertension in Adult and Paediatric Traumatic Brain Injury. Intensive Care Med. 41, 1067-1076. doi:10.1007/s00134-015-3806-1

Güiza, F., Meyfroidt, G., Piper, I., Citerio, G., Chambers, I., Enblad, P., et al. (2017). Cerebral Perfusion Pressure Insults and Associations with Outcome in Adult Traumatic Brain Injury. J. Neurotrauma 34, 2425-2431. doi:10.1089/ neu.2016.4807

Hamel, E., Nicolakakis, N., Aboulkassim, T., Ongali, B., and Tong, X. K. (2008). Oxidative Stress and Cerebrovascular Dysfunction in Mouse Models of Alzheimer's Disease. Exp. Physiol. 93, 116-120. doi:10.1113/expphysiol.2007.038729

Hawryluk, G. W. J., Aguilera, S., Buki, A., Bulger, E., Citerio, G., Cooper, D. J., et al. (2019). A Management Algorithm for Patients with Intracranial Pressure Monitoring: the Seattle International Severe Traumatic Brain Injury Consensus Conference (SIBICC). Intensive Care Med. 45, 1783-1794. doi:10.1007/s00134-019-05805-9

Hawryluk, G. W. J., Nielson, J. L., Huie, J. R., Zimmermann, L., Saigal, R., Ding, Q., et al. (2020). Analysis of Normal High-Frequency Intracranial Pressure Values and Treatment Threshold in Neurocritical Care Patients: Insights into Normal Values and a Potential Treatment Threshold. JAMA Neurol. 77 (9), 1150-1158. doi:10.1001/jamaneurol.2020.1310

Helmy, A., Carpenter, K. L., Menon, D. K., Pickard, J. D., and Hutchinson, P. J. (2011). The Cytokine Response to Human Traumatic Brain Injury: Temporal Profiles and Evidence for Cerebral Parenchymal Production. J. Cereb. Blood Flow Metab. 31, 658-670. doi:10.1038/jcbfm.2010.142

Helmy, A., Guilfoyle, M. R., Carpenter, K. L., and Hutchinson, P. J. (2011). Sex and the Cytokines: Are There Fundamental Differences in Response to Brain Injury? Neurosurgery 69, E1029-E1030. doi:10.1227/ NEU.0b013e3182299839

Howells, T., Lewén, A., Sköld, M. K., Ronne-Engström, E., and Enblad, P. (2012). An Evaluation of Three Measures of Intracranial Compliance in Traumatic Brain Injury Patients. Intensive Care Med. 38, 1061-1068. doi:10.1007/s00134012-2571-7

Hu, K., Peng, C. K., Czosnyka, M., Zhao, P., and Novak, V. (2008). Nonlinear Assessment of Cerebral Autoregulation from Spontaneous Blood Pressure and Cerebral Blood Flow Fluctuations. Cardiovasc. Eng. 8, 60-71. doi:10.1007/ s10558-007-9045-5 
Hutchinson, P. J., Jalloh, I., Helmy, A., Carpenter, K. L., Rostami, E., Bellander, B. M., et al. (2015). Consensus Statement from the 2014 International Microdialysis Forum. Intensive Care Med. 41, 1517-1528. doi:10.1007/ s00134-015-3930-y

Hutchinson, P., and O'Phelan, K. (2014). Participants in the International Multidisciplinary Consensus Conference on Multimodality MonitoringInternational Multidisciplinary Consensus Conference on Multimodality Monitoring: Cerebral Metabolism. Neurocrit. Care 21 (Suppl. 2), S148-S158. doi:10.1007/s12028-014-0035-3

Ishikawa, N., Nakamura, K., Izumiyama-Shimomura, N., Aida, J., Matsuda, Y., Arai, T., et al. (2016). Changes of Telomere Status with Aging: An Update. Geriatr. Gerontol. Int. 16 (Suppl. 1), 30-42. doi:10.1111/ ggi.12772

Khaksari, M., Soltani, Z., and Shahrokhi, N. (2018). Effects of Female Sex Steroids Administration on Pathophysiologic Mechanisms in Traumatic Brain Injury. Transl. Stroke Res. 9, 393-416. doi:10.1007/s12975-017-0588-5

Kim, D. J., Czosnyka, Z., Keong, N., Radolovich, D. K., Smielewski, P., Sutcliffe, M. P., et al. (2009). Index of Cerebrospinal Compensatory reserve in Hydrocephalus. Neurosurgery 64, 494-502. doi:10.1227/ 01.NEU.0000338434.59141.89

Klein, T., Bailey, T. G., Wollseiffen, P., Schneider, S., and Askew, C. D. (2020). The Effect of Age on Cerebral Blood Flow Responses during Repeated and Sustained Stand to Sit Transitions. Physiol. Rep. 8, e14421. doi:10.14814/phy2.14421

Korley, F., Pauls, Q., Yeatts, S. D., Jones, C. M. C., Corbett-Valade, E., Silbergleit, R., et al. (2021). Progesterone Treatment Does Not Decrease Serum Levels of Biomarkers of Glial and Neuronal Cell Injury in Moderate and Severe Traumatic Brain Injury Subjects: A Secondary Analysis of the Progesterone for Traumatic Brain Injury, Experimental Clinical Treatment (ProTECT) III Trial. J. Neurotrauma 38, 1953-1960. doi:10.1089/neu.2020.7072

Krause, D. N., Duckles, S. P., and Pelligrino, D. A. (1985). Influence of Sex Steroid Hormones on Cerebrovascular Function. J. Appl. Physiol. 101, 1252-1261. doi:10.1152/japplphysiol.01095.2005

Kurtz, P., Claassen, J., Schmidt, J. M., Helbok, R., Hanafy, K. A., Presciutti, M., et al. (2013). Reduced Brain/serum Glucose Ratios Predict Cerebral Metabolic Distress and Mortality after Severe Brain Injury. Neurocrit. Care 19, 311-319. doi:10.1007/s12028-013-9919-x

Le Roux, P., Menon, D. K., Citerio, G., Vespa, P., Bader, M. K., Brophy, G. M., et al. (2014). Consensus Summary Statement of the International Multidisciplinary Consensus Conference on Multimodality Monitoring in Neurocritical Care: a Statement for Healthcare Professionals from the Neurocritical Care Society and the European Society of Intensive Care Medicine. Neurocrit. Care 21 (Suppl. 2), S1-S26. doi:10.1007/s12028014-0041-5

Lingsma, H., Andriessen, T. M., Haitsema, I., Horn, J., van der Naalt, J., Franschman, G., et al. (2013). Prognosis in Moderate and Severe Traumatic Brain Injury: External Validation of the IMPACT Models and the Role of Extracranial Injuries. J. Trauma Acute Care Surg. 74, 639-646. doi:10.1097/ TA.0b013e31827d602e

Low, A., Mak, E., Rowe, J. B., Markus, H. S., and O'Brien, J. T. (2019). Inflammation and Cerebral Small Vessel Disease: A Systematic Review. Ageing Res. Rev. 53, 100916. doi:10.1016/j.arr.2019.100916

Lu, X. Y., Sun, H., Li, Q. Y., and Lu, P. S. (2016). Progesterone for Traumatic Brain Injury: A Meta-Analysis Review of Randomized Controlled Trials. World Neurosurg. 90, 199-210. doi:10.1016/j.wneu.2016.02.110

Ma, J., Huang, S., Qin, S., You, C., and Zeng, Y. (2016). Progesterone for Acute Traumatic Brain Injury. Cochrane Database Syst. Rev. 12, CD008409. doi:10.1002/14651858.CD008409.pub4

Maas, A. I., Menon, D. K., Steyerberg, E. W., Citerio, G., Lecky, F., Manley, G. T., et al. (2015). Collaborative European NeuroTrauma Effectiveness Research in Traumatic Brain Injury (CENTER-TBI): a Prospective Longitudinal Observational Study. Neurosurgery 76, 67-80. doi:10.1227/NEU.0000000000000575

Maas, A. I. R., Menon, D. K., Adelson, P. D., Andelic, N., Bell, M. J., Belli, A., et al. (2017). Traumatic Brain Injury: Integrated Approaches to Improve Prevention, Clinical Care, and Research. Lancet Neurol. 16, 987-1048. doi:10.1016/S14744422(17)30371-X

Mariappan, R., Mehta, J., Chui, J., Manninen, P., and Venkatraghavan, L. (2015). Cerebrovascular Reactivity to Carbon Dioxide under Anesthesia: a Qualitative
Systematic Review. J. Neurosurg. Anesthesiol. 27, 123-135. doi:10.1097/ ANA.0000000000000092

Martin-Jiménez, C., Gaitán-Vaca, D. M., Areiza, N., Echeverria, V., Ashraf, G. M., González, J., et al. (2019). Astrocytes Mediate Protective Actions of Estrogenic Compounds after Traumatic Brain Injury. Neuroendocrinology 108, 142-160. doi: $10.1159 / 000495078$

Martini, R. P., Deem, S., Yanez, N. D., Chesnut, R. M., Weiss, N. S., Daniel, S., et al. (2009). Management Guided by Brain Tissue Oxygen Monitoring and Outcome Following Severe Traumatic Brain Injury. J. Neurosurg. 111, 644-649. doi:10.3171/2009.2.JNS08998

Mathieu, F., Khellaf, A., Ku, J. C., Donnelly, J., Thelin, E. P., and Zeiler, F. A. (2020). Continuous Near-Infrared Spectroscopy Monitoring in Adult Traumatic Brain Injury: A Systematic Review. J. Neurosurg. Anesthesiol. 32, 288-299. doi:10.1097/ANA.0000000000000620

Mathieu, F., Khellaf, A., Thelin, E. P., and Zeiler, F. A. (2019). Continuous Thermal Diffusion-Based Cerebral Blood Flow Monitoring in Adult Traumatic Brain Injury: A Scoping Systematic Review. J. Neurotrauma 36, 1707-1723. doi:10.1089/neu.2018.6309

Mathieu, F., Khellaf, A., Ku, J. C., Donnelly, J., Thelin, E. P., and Zeiler, F. A. (2019). Continuous Near-Infrared Spectroscopy Monitoring in Adult Traumatic Brain Injury: A Systematic Review. J. Neurosurg. Anesthesiol. 32 (4), 288-299. doi:10.1097/ANA.0000000000000620

McKetton, L., Sobczyk, O., Duffin, J., Poublanc, J., Sam, K., Crawley, A. P., et al. (2018). The Aging Brain and Cerebrovascular Reactivity. NeuroImage 181, 132-141. doi:10.1016/j.neuroimage.2018.07.007

Mellergård, P., Sjögren, F., and Hillman, J. (2012). The Cerebral Extracellular Release of Glycerol, Glutamate, and FGF2 Is Increased in Older Patients Following Severe Traumatic Brain Injury. J. Neurotrauma 29, 112-118. doi:10.1089/neu.2010.1732

Mészáros, Á., Molnár, K., Nógrádi, B., Hernádi, Z., Nyúl-Tóth, Á., Wilhelm, I., et al. (2020). Neurovascular Inflammaging in Health and Disease. Cells 9, 1614. doi:10.3390/cells9071614

Mikolić, A., van Klaveren, D., Groeniger, J. O., Wiegers, E. J. A., Lingsma, H. F., Zeldovich, M., et al. (2021). Differences between Men and Women in Treatment and Outcome after Traumatic Brain Injury. J. Neurotrauma 38, 235-251. doi:10.1089/neu.2020.7228

Mikolic, A., van Klaveren, D., Oude Groeniger, J., Wiegers, E., Lingsma, H. F., Zeldovich, M., et al. (2020). Differences between Men and Women in Treatment and Outcome Following Traumatic Brain Injury. J. Neurotrauma 38 (2), 235-251. doi:10.1089/neu.2020.7228

Miller, K. B., Howery, A. J., Rivera-Rivera, L. A., Johnson, S. C., Rowley, H. A., Wieben, O., et al. (2019). Age-Related Reductions in Cerebrovascular Reactivity Using 4D Flow MRI. Front. Aging Neurosci. 11, 281. doi:10.3389/ fnagi.2019.00281

Newman, L., Nolan, H., Carey, D., Reilly, R. B., and Kenny, R. A. (2020). Age and Sex Differences in Frontal Lobe Cerebral Oxygenation in Older AdultsNormative Values Using Novel, Scalable Technology: Findings from the Irish Longitudinal Study on Ageing (TILDA). Arch. Gerontol. Geriatr. 87, 103988. doi:10.1016/j.archger.2019.103988

Nourallah, B., Zeiler, F. A., Calviello, L., Smielewski, P., Czosnyka, M., and Menon, D. K. (2018). Critical Thresholds for Intracranial Pressure Vary over Time in Non-craniectomised Traumatic Brain Injury Patients. Acta Neurochir. (Wien) 160, 1315-1324. doi:10.1007/s00701-018-3555-3

Okonkwo, D. O., Shutter, L. A., Moore, C., Temkin, N. R., Puccio, A. M., Madden, C. J., et al. (2017). Brain Oxygen Optimization in Severe Traumatic Brain Injury Phase-II: A Phase II Randomized Trial. Crit. Care Med. 45, 1907-1914. doi:10.1097/CCM.0000000000002619

Pan, Z. Y., Zhao, Y. H., Huang, W. H., Xiao, Z. Z., and Li, Z. Q. (2019). Effect of Progesterone Administration on the Prognosis of Patients with Severe Traumatic Brain Injury: a Meta-Analysis of Randomized Clinical Trials. Drug Des. Devel. Ther. 13, 265-273. doi:10.2147/DDDT.S192633

Qi, X. M., and Ma, J. F. (2017). The Role of Amyloid Beta Clearance in Cerebral Amyloid Angiopathy: More Potential Therapeutic Targets. Transl. Neurodegener. 6, 22. doi:10.1186/s40035-017-0091-7

Reed, J. T., Pareek, T., Sriramula, S., and Pabbidi, M. R. (2020). Aging Influences Cerebrovascular Myogenic Reactivity and BK Channel Function in a Sexspecific Manner. Cardiovasc. Res. 116, 1372-1385. doi:10.1093/cvr/cvz314 
Robu, C. B., Koninckx, A., Docquier, M. A., Grosu, I., De Kerchove, L., Mastrobuoni, S., et al. (2020). Advanced Age and Sex Influence Baseline Regional Cerebral Oxygen Saturation as Measured by Near-Infrared Spectroscopy: Subanalysis of a Prospective Study. J. Cardiothorac. Vasc. Anesth. 34, 3282-3289. doi:10.1053/j.jvca.2020.06.025

Rosenthal, G., Sanchez-Mejia, R. O., Phan, N., Hemphill, J. C., Martin, C., and Manley, G. T. (2011). Incorporating a Parenchymal thermal Diffusion Cerebral Blood Flow Probe in Bedside Assessment of Cerebral Autoregulation and Vasoreactivity in Patients with Severe Traumatic Brain Injury. J. Neurosurg. 114, 62-70. doi:10.3171/2010.6.JNS091360

Schumacher, M., Denier, C., Oudinet, J. P., Adams, D., and Guennoun, R. (2016). Progesterone Neuroprotection: The Background of Clinical Trial Failure. J. Steroid Biochem. Mol. Biol. 160, 53-66. doi:10.1016/ j.jsbmb.2015.11.010

Skolnick, B. E., Maas, A. I., Narayan, R. K., van der Hoop, R. G., MacAllister, T., Ward, J. D., et al. (2014). A Clinical Trial of Progesterone for Severe Traumatic Brain Injury. N. Engl. J. Med. 371, 2467-2476. doi:10.1056/NEJMoa1411090

Smieleweski, P., and Czosnyka, M. (2000-2021). Intensive Care Monitoring Plus $(\mathrm{ICM}+)$ Data Acquisition Software. Cambridge, United Kingdom: Cambridge Enterprises.

Sorrentino, E., Budohoski, K. P., Kasprowicz, M., Smielewski, P., Matta, B., Pickard, J. D., et al. (2011). Critical Thresholds for Transcranial Doppler Indices of Cerebral Autoregulation in Traumatic Brain Injury. Neurocrit. Care 14, 188-193. doi:10.1007/s12028-010-9492-5

Sorrentino, E., Diedler, J., Kasprowicz, M., Budohoski, K. P., Haubrich, C., Smielewski, P., et al. (2012). Critical Thresholds for Cerebrovascular Reactivity after Traumatic Brain Injury. Neurocrit. Care 16, 258-266. doi:10.1007/s12028-011-9630-8

Späni, C. B., Braun, D. J., and Van Eldik, L. J. (2018). Sex-related Responses after Traumatic Brain Injury: Considerations for Preclinical Modeling. Front. Neuroendocrinol. 50, 52-66. doi:10.1016/j.yfrne.2018.03.006

Stein, N. R., McArthur, D. L., Etchepare, M., and Vespa, P. M. (2012). Early Cerebral Metabolic Crisis after TBI Influences Outcome Despite Adequate Hemodynamic Resuscitation. Neurocrit. Care 17, 49-57. doi:10.1007/s12028012-9708-y

Steyerberg, E. W., Wiegers, E., Sewalt, C., Buki, A., Citerio, G., De Keyser, V., et al. (2019). Case-mix, Care Pathways, and Outcomes in Patients with Traumatic Brain Injury in CENTER-TBI: a European Prospective, Multicentre, Longitudinal, Cohort Study. Lancet Neurol. 18, 923-934. doi:10.1016/S1474-4422(19)30232-7

Stiefel, M. F., Spiotta, A., Gracias, V. H., Garuffe, A. M., Guillamondegui, O., Maloney-Wilensky, E., et al. (2005). Reduced Mortality Rate in Patients with Severe Traumatic Brain Injury Treated with Brain Tissue Oxygen Monitoring. J. Neurosurg. 103, 805-811. doi:10.3171/jns.2005.103.5.0805

Taneja, K., Liu, P., Xu, C., Turner, M., Zhao, Y., Abdelkarim, D., et al. (2020). Quantitative Cerebrovascular Reactivity in Normal Aging: Comparison between Phase-Contrast and Arterial Spin Labeling MRI. Front. Neurol. 11, 758. doi:10.3389/fneur.2020.00758

Thelin, E. P., Hall, C. E., Gupta, K., Carpenter, K. L. H., Chandran, S., Hutchinson, P. J., et al. (2018). Elucidating Pro-inflammatory Cytokine Responses after Traumatic Brain Injury in a Human Stem Cell Model. J. Neurotrauma 35, 341-352. doi:10.1089/neu.2017.5155

Thelin, E. P., Tajsic, T., Zeiler, F. A., Menon, D. K., Hutchinson, P. J. A., Carpenter, K. L. H., et al. (2017). Monitoring the Neuroinflammatory Response Following Acute Brain Injury. Front. Neurol. 8, 351. doi:10.3389/fneur.2017.00351

Thelin, E. P., Zeiler, F. A., Ercole, A., Mondello, S., Büki, A., Bellander, B. M., et al. (2017). Serial Sampling of Serum Protein Biomarkers for Monitoring Human Traumatic Brain Injury Dynamics: A Systematic Review. Front. Neurol. 8, 300. doi:10.3389/fneur.2017.00300

Thelin, E. P., Raj, R., Bellander, B.-M., Nelson, D., Piippo-Karjalainen, A., Siironen, J., et al. (2019). Comparison of High versus Low Frequency Cerebral Physiology for Cerebrovascular Reactivity Assessment in Traumatic Brain Injury: a Multicenter Pilot Study. J. Clin. Monit. Comput. 34 (5), 971-994. doi:10.1007/s10877019-00392-y

Timofeev, I., Carpenter, K. L., Nortje, J., Al-Rawi, P. G., O'Connell, M. T., Czosnyka, M., et al. (2011). Cerebral Extracellular Chemistry and Outcome Following Traumatic Brain Injury: a Microdialysis Study of 223 Patients. Brain 134, 484-494. doi:10.1093/brain/awq353
Tomoto, T., Riley, J., Turner, M., Zhang, R., and Tarumi, T. (2020). Cerebral Vasomotor Reactivity during Hypo- and Hypercapnia across the Adult Lifespan. J. Cereb. Blood Flow Metab. 40, 600-610. doi:10.1177/ 0271678X19828327

Wang, X., Liu, Y., Jia, Y., Liu, H., Bao, X., He, Z., et al. (2019). Proteome Profiling of Cerebral Vessels in Rhesus Macaques: Dysregulation of Antioxidant Activity and Extracellular Matrix Proteins Contributes to Cerebrovascular Aging in Rhesus Macaques. Front. Aging Neurosci. 11, 293. doi:10.3389/fnagi.2019.00293

Weller, R. O., Hawkes, C. A., Kalaria, R. N., Werring, D. J., and Carare, R. O. (2015). White Matter Changes in Dementia: Role of Impaired Drainage of Interstitial Fluid. Brain Pathol. 25, 63-78. doi:10.1111/bpa.12218

Wright, D. W., Kellermann, A. L., Hertzberg, V. S., Clark, P. L., Frankel, M., Goldstein, F. C., et al. (2007). ProTECT: a Randomized Clinical Trial of Progesterone for Acute Traumatic Brain Injury. Ann. Emerg. Med. 49, 391e1-4022. doi:10.1016/j.annemergmed.2006.07.932

Yilmaz, C., Karali, K., Fodelianaki, G., Gravanis, A., Chavakis, T., Charalampopoulos, I., et al. (2019). Neurosteroids as Regulators of Neuroinflammation. Front. Neuroendocrinol. 55, 100788. doi:10.1016/ j.yfrne.2019.100788

Zarzour, A., Kim, H. W., and Weintraub, N. L. (2019). Epigenetic Regulation of Vascular Diseases. Arterioscler Thromb. Vasc. Biol. 39, 984-990. doi:10.1161/ ATVBAHA.119.312193

Zeiler, F. A., Beqiri, E., Cabeleira, M., Hutchinson, P. J., Stocchetti, N., Menon, D. K., et al. (2020). Brain Tissue Oxygen and Cerebrovascular Reactivity in Traumatic Brain Injury: A Collaborative European NeuroTrauma Effectiveness Research in Traumatic Brain Injury Exploratory Analysis of Insult Burden. J. Neurotrauma 37, 1854-1863. doi:10.1089/neu.2020.7024

Zeiler, F. A., Donnelly, J., Calviello, L., Menon, D. K., Smielewski, P., and Czosnyka, M. (2017). Pressure Autoregulation Measurement Techniques in Adult Traumatic Brain Injury, Part I: A Scoping Review of Intermittent/Semi-Intermittent Methods. J. Neurotrauma 34, 3207-3223. doi:10.1089/neu.2017.5085

Zeiler, F. A., Donnelly, J., Calviello, L., Smielewski, P., Menon, D. K., and Czosnyka, M. (2017). Pressure Autoregulation Measurement Techniques in Adult Traumatic Brain Injury, Part II: A Scoping Review of Continuous Methods. J. Neurotrauma 34, 3224-3237. doi:10.1089/neu.2017.5086

Zeiler, F. A., Donnelly, J., Menon, D. K., Smielewski, P., Zweifel, C., Brady, K., et al. (2017). Continuous Autoregulatory Indices Derived from Multi-Modal Monitoring: Each One Is Not like the Other. J. Neurotrauma 34, 3070-3080. doi:10.1089/neu.2017.5129

Zeiler, F. A., Donnelly, J., Nourallah, B., Thelin, E. P., Calviello, L., Smielewski, P., et al. (2018). Intracranial and Extracranial Injury Burden as Drivers of Impaired Cerebrovascular Reactivity in Traumatic Brain Injury. J. Neurotrauma 35, 1569-1577. doi:10.1089/neu.2017.5595

Zeiler, F. A., Ercole, A., Beqiri, E., Cabeleira, M., Aries, M., Zoerle, T., et al. (2019). Cerebrovascular Reactivity Is Not Associated with Therapeutic Intensity in Adult Traumatic Brain Injury: a CENTER-TBI Analysis. Acta Neurochir. (Wien) 161, 1955-1964. doi:10.1007/s00701-019-03980-8

Zeiler, F. A., Ercole, A., Cabeleira, M., Stocchetti, N., Hutchinson, P. J., Smielewski, P., et al. (2020). Descriptive Analysis of Low versus Elevated Intracranial Pressure on Cerebral Physiology in Adult Traumatic Brain Injury: a CENTER-TBI Exploratory Study. Acta Neurochir. (Wien) 162, 2695-2706. doi:10.1007/s00701-020-04485-5

Zeiler, F. A., Ercole, A., Cabeleira, M., Zoerle, T., Stocchetti, N., Menon, D. K., et al. (2019). Univariate Comparison of Performance of Different Cerebrovascular Reactivity Indices for Outcome Association in Adult TBI: a CENTER-TBI Study. Acta Neurochir. (Wien) 161, 1217-1227. doi:10.1007/s00701-01903844-1

Zeiler, F. A., Ercole, A., Placek, M. M., Hutchinson, P. J., Stocchetti, N., Czosnyka, M., et al. (2020). Association between Physiological Signal Complexity and Outcomes in Moderate and Severe Traumatic Brain Injury: A CENTER-TBI Exploratory Analysis of Multi-Scale Entropy. J. Neurotrauma 38 (2), 272-282. doi:10.1089/neu.2020.7249

Zeiler, F. A., Kim, D. J., Cabeleira, M., Calviello, L., Smielewski, P., and Czosnyka, M. (2018). Impaired Cerebral Compensatory reserve Is Associated with Admission Imaging Characteristics of Diffuse Insult in Traumatic Brain Injury. Acta Neurochir. (Wien) 160, 2277-2287. doi:10.1007/s00701-018-3681-y 
Zeiler, F. A., Thelin, E. P., Czosnyka, M., Hutchinson, P. J., Menon, D. K., and Helmy, A. (2017). Cerebrospinal Fluid and Microdialysis Cytokines in Severe Traumatic Brain Injury: A Scoping Systematic Review. Front. Neurol. 8, 331. doi:10.3389/fneur.2017.00331

Zeiler, F. A., Thelin, E. P., Donnelly, J., Stevens, A. R., Smielewski, P., Czosnyka, M., et al. (2019). Genetic Drivers of Cerebral Blood Flow Dysfunction in TBI: a Speculative Synthesis. Nat. Rev. Neurol. 15, 25-39. doi:10.1038/s41582-018-0105-9

Zeiler, F. A., Thelin, E. P., Helmy, A., Czosnyka, M., Hutchinson, P. J. A., and Menon, D. K. (2017). A Systematic Review of Cerebral Microdialysis and Outcomes in TBI: Relationships to Patient Functional Outcome, Neurophysiologic Measures, and Tissue Outcome. Acta Neurochir (Wien) 159, 2245-2273. doi:10.1007/s00701-017-3338-2

Zeiler, F. A., Aries, M., Cabeleira, M., van Essen, T., Stocchetti, N., Menon, D., et al. (2020). Statistical Cerebrovascular Reactivity Signal Properties after Secondary Decompressive Craniectomy in Traumatic Brain Injury: A CENTER-TBI Pilot Analysis. J. Neurotrauma. 37 (11), 1306-1314. doi:10.1089/neu.2019.6726

Zeiler, F. A., Cabeleira, M., Hutchinson, P. J., Stocchetti, N., Czosnyka, M., Smielewski, P., et al. (2020). Evaluation of the Relationship between SlowWaves of Intracranial Pressure, Mean Arterial Pressure and Brain Tissue Oxygen in TBI: a CENTER-TBI Exploratory Analysis. J. Clin. Monit. Comput. 35 (4), 711-722. doi:10.1007/s10877-020-00527-6

Zeiler, F. A., Donnelly, J., Smielewski, P., Menon, D. K., Hutchinson, P. J., and Czosnyka, M. (2018). Critical Thresholds of Intracranial Pressure-Derived Continuous Cerebrovascular Reactivity Indices for Outcome Prediction in Noncraniectomized Patients with Traumatic Brain Injury. J. Neurotrauma 35, 1107-1115. doi:10.1089/neu.2017.5472

Zeiler, F. A., Ercole, A., Beqiri, E., Cabeleira, M., Thelin, E. P., Stocchetti, N., et al. (2019). Association between Cerebrovascular Reactivity Monitoring and Mortality Is Preserved when Adjusting for Baseline Admission Characteristics in Adult TBI: A CENTER-TBI Study. J. Neurotrauma 37 (10), 1233-1241. doi:10.1089/neu.2019.6808

Zeiler, F. A., Ercole, A., Czosnyka, M., Smielewski, P., Hawryluk, G., Hutchinson, P. J. A., et al. (2020). Continuous Cerebrovascular Reactivity Monitoring in Moderate/severe Traumatic Brain Injury: A Narrative Review of Advances in Neurocritical Care. Br. J. Anaesth. 124 (4), 440-453. doi:10.1016/j.bja.2019.11.031
Zeiler, F. A., Ercole, A., Ercole, A., Cabeleira, M., Beqiri, E., Zoerle, T., et al. (2019). High Resolution ICU Sub-study Participants and InvestigatorsCompensatoryreserve-weighted Intracranial Pressure versus Intracranial Pressure for Outcome Association in Adult Traumatic Brain Injury: a CENTER-TBI Validation Study. Acta Neurochir. 161, 1275-1284. doi:10.1007/s00701-01903915-3

Zeiler, F. A., McFadyen, C., Newcombe, V. F. J., Synnot, A., Donoghue, E. L., Ripatti, S., et al. (2019). Genetic Influences on Patient-Oriented Outcomes in Traumatic Brain Injury: A Living Systematic Review of Non-apolipoprotein E Single-Nucleotide Polymorphisms. J. Neurotrauma 38 (8), 1107-1123. doi:10.1089/neu.2017.5583

Zeiler, F. A., Unger, B., West, M., Kazina, C. J., Berrington, N., and Ellis, M. J. (2018). Manitoba Cranial Neurotrauma Research - Past, Present and Future. J. Neurotrauma 35, 1999-2001. doi:10.1089/neu.2017.5596

Zweifel, C., Castellani, G., Czosnyka, M., Helmy, A., Manktelow, A., Carrera, E., et al. (2010). Noninvasive Monitoring of Cerebrovascular Reactivity with Near Infrared Spectroscopy in Head-Injured Patients. J. Neurotrauma 27, 1951-1958. doi:10.1089/neu.2010.1388

Conflict of Interest: The authors declare that the research was conducted in the absence of any commercial or financial relationships that could be construed as a potential conflict of interest.

Publisher's Note: All claims expressed in this article are solely those of the authors and do not necessarily represent those of their affiliated organizations, or those of the publisher, the editors and the reviewers. Any product that may be evaluated in this article, or claim that may be made by its manufacturer, is not guaranteed or endorsed by the publisher.

Copyright (C) 2021 Batson, Gomez, Sainbhi, Froese and Zeiler. This is an open-access article distributed under the terms of the Creative Commons Attribution License (CC $B Y)$. The use, distribution or reproduction in other forums is permitted, provided the original author(s) and the copyright owner(s) are credited and that the original publication in this journal is cited, in accordance with accepted academic practice. No use, distribution or reproduction is permitted which does not comply with these terms. 